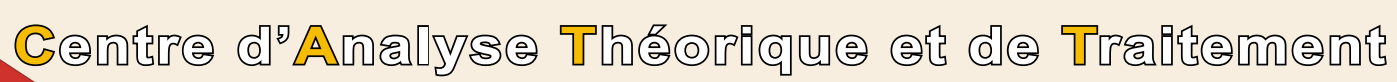

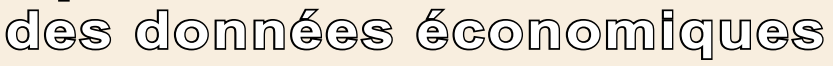

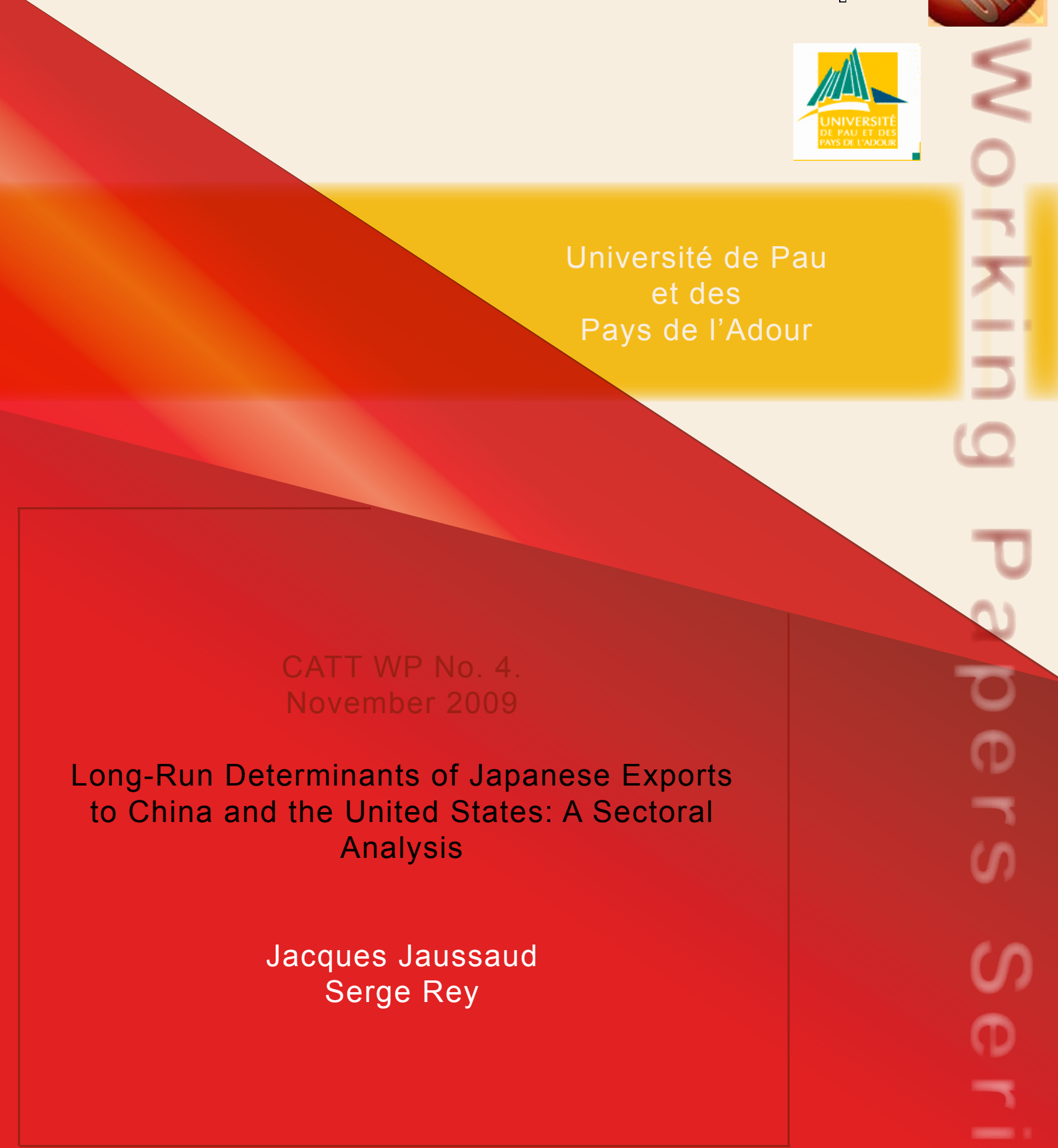

ong-Run Determinants of Japanese Exports to China and the United States: A Sectoral Analysis

Jacques Jaussaud Serge Rey 


\title{
Long-Run Determinants of Japanese Exports to China and the United States: A Sectoral Analysis
}

\author{
April 2009
}

\author{
Jacques JAUSSAUD \\ CREG, University of Pau, 64016 Pau, France \\ Serge REY ${ }^{a, b}$ \\ ${ }^{a}$ University of Grenoble 2, 38040 Grenoble, France \\ ${ }^{b}$ CATT, University of Pau, 64016 Pau, France
}

Keywords: Exchange rate, Yen, Exports, International Trade, Japan, Long-run relationships.

JEL Classification: C13, C22, F31, F32, F39.

Correspondence Address: Serge REY, Department of Economics, C.A.T.T, University of Pau. Avenue du Doyen Poplawski, B.P. 1633, 64016 Pau Cedex, France. (E-mail) serge.rey@univ-pau.fr. 


\title{
Long-Run Determinants of Japanese Exports to China and the United States: A Sectoral Analysis
}

\begin{abstract}
:
We show that during the period 1971-2007, Japanese sectoral exports to China and the United States have depended on real exchange rate fluctuations and external demand (gross domestic product of the country of destination). This result holds for six sectors: foods, textile, metal products, chemicals, non-metal products, and machinery and equipment, as well as for both geographical destinations. Generally, the real exchange rate fluctuations and GDP have had the expected effects. In particular, a real appreciation of the yen and a bigger uncertainty has reduced the Japanese exports. But there is an important exception, as we find a price inelasticity of the principal Japanese exports to USA, i.e. Machinery and Equipment, which represent 80 percent of total exports to USA. So, a real depreciation of the yen may constitute an inappropriate policy to favor a process of growth export-led.
\end{abstract}

\section{Introduction}

Recent observations about the international economy have confirmed the dependence, the vulnerability of the external trade of the world's second-largest economy. So, after a big fall of her exports, Japan has recorded in February 2009 a huge trade deficit of 952,6 billion yen, the most important deficit after the 824,8 billion yen in January 1980, following the second oil crisis. An obvious explanation of this situation is the weakness of the external demand which results from the ongoing international crisis. However, several questions concerning the importance of Japanese exports remain: to which extent the Japanese growth depends on the exports? Which roles play the main partners? Which are the fundamentals variables of the Japanese exports?

We know that, since the 1950s, Japanese exports have played an important role in the process of Japanese growth. Boltho (1996) concludes that if "domestic forces propelled longer-run growth, exports may have been crucial in initiating several cyclical upswings". For the period 1960-1999, Hatemi-J (2002) shows that we have a bidirectional causality between exports and growth of Japan. More recently, Chen and Hsiao (2008) find evidence that the Chinese growth has causal effects on Japanese growth. These recent papers confirm that exports can lead growth and allow the Japanese economy to exit out of the recession.

The questions of partners and explanatory variables of exports can't be dissociated. Indeed, the orthodox model considers the income and the relative price (real exchange rate) as 
principal explanatory variables. In these conditions, Japanese exports will be dependent on the economic growth of partners and the behavior of exchange rate of the yen. The recent debate about the undervaluation of the Chinese renminbi (RMB) highlights the importance of fluctuations of exchange rates in international trade. Because of sharp criticisms from the United States, most observers focus on dollar-RMB parity, yet this approach is limited in scope. By concentrating on the American deficit, these critics tend to neglect the importance of trade between China and Asia, especially with Japan. In terms of foreign direct investments (FDI), Japan is also a privileged partner of China. In this respect, Chinese authorities' decision to anchor the RMB to the American dollar is not without consequences. As they seek to stabilize their exchange rate, Chinese authorities must recognize that every fluctuation in dollar/yen parity affects RMB/yen parity.

So, in a period of crisis as the one we are experiencing in 2008-2009, which is characterized by a big drop of external demand, the exchange rate can provide an important leverage to lead growth, on condition that exports are sensitive to exchange rate fluctuations, considered in terms of level and volatility (Klein, 2000). And this point is far from being established. For example, Nagayasu (2007) concludes that in the long run the real exchange rate of the yen does not cause Japanese growth, a result which is consistent with the conclusion of Miyao (2003) who finds no significant relation between the yen exchange rate and the Japanese trade balance since the middle of $1980 \mathrm{~s}^{1}$. Bahmani-Oskooe and Hegerty (2009) study the relation between the real exchange rate of the yen and the Japan's trade balances with the USA for 117 industries. They find that depreciation of the yen causes the trade balance to improve in the long-run for only one-third of Japanese industries ${ }^{2}$. But these studies do not analyze in detail the Japanese exports. Either they consider trade balances without distinction between imports and exports, or they analyze the overall exports of Japan. In other words, they cannot explain why the trade balance is or is not impacted by exchange rate fluctuations and external demand, and by which channels of transmission.

Thus we consider that a study of sectoral exports with the principal partners of Japan is required. Which partners should we consider? The USA is the first destination for Japanese exports $(22.9 \%$ of total exports in 2005). The European Union and China follow with

\footnotetext{
${ }^{1}$ Choudhry (2005) finds that greater volatility in the exchange rate of the dollar against the yen (both nominal and real rates) has negative effects on exports from the United States to Japan.

${ }^{2}$ Note that they do not take into account of the exchange rate volatility in their models. Besides, they do not retain exports prices to calculate real exchange rates, but consumer prices for every country.
} 
respectively $14.7 \%$ and $13.5 \%$ of total exports. So the USA and China represent more than one third of total exports of Japan. On the import side, China ranks first $(21.1 \%$ of total Japanese imports in 2005), before the USA (12.7\% in 2005). In other words, the USA and China are two major different trading partners of Japan.

We therefore analyze in this contribution the question of the sensitivity of the exports of Japan to fluctuations of the exchange rate and to external demand in two different contexts:

- between Japan and the United States, two developed nations with a long history of interactions;

- between nations at different levels of development, namely, China and Japan, keeping in mind that China has long represented a privileged ground for the delocalization for the Japanese firms.

To analyze the long run determinants of Japanese exports by sectors, we proceed as follows. First, we present a brief overview of the evolution of exports from Japan to China and the United States during the period under investigation, the beginning of the 1970s to the present. Second, we estimate the functions of exports from Japan to China and the United States. We consider exports by sectors for each destination, because companies from different industries do not react in the same way to the fluctuations in the exchange rate. They instead adapt their export prices and their margins distinctly, as the competitive environment differs according to the industry and the country of destination (Porter, 1986; Parsons and Sato, 2008). As a consequence, the impact of exchange rate variability should differ from one sector to another. Third, we undertake an econometric estimate of the functions of exports, based on a standard approach in terms of cointegration. Specifically, we employ the Saikkonen-Lütkepohl method, which takes into account the presence of breaks in the variables, to investigate the long-run relationships among our variables from over the period 1971-2007.

\section{Background}

During the period under investigation, Japanese foreign trade experienced various effects in various economic contexts. At the beginning of the 1980s, Japan emerged as a major exporter and accumulated an exploding trade surplus (see Figure 1) as the United States maintained a tight monetary policy that led to a strong dollar. Trade frictions intensified 
between Japan and the United States and, to a lesser extent, Europe. Various mechanisms, usually established through negotiation, have attempted to manage trade between Japan and her different partners.

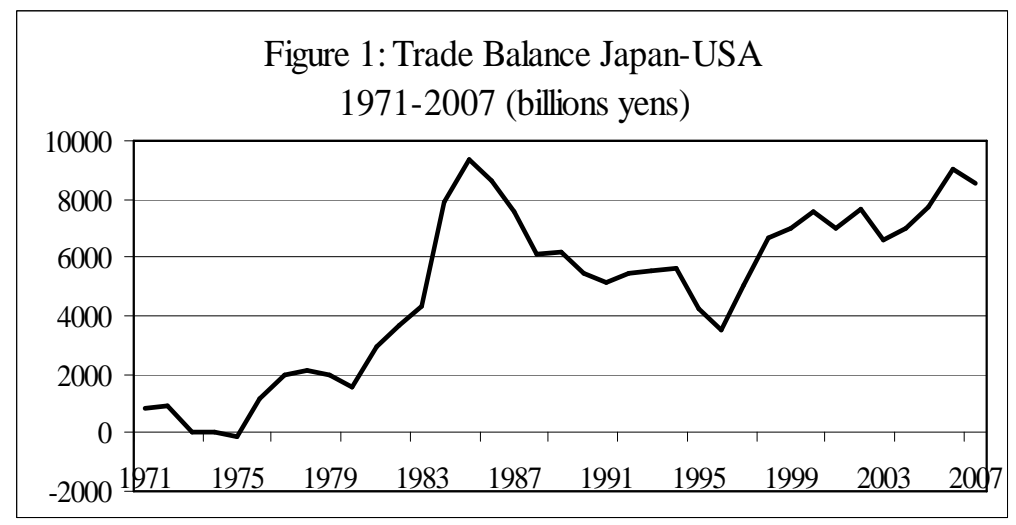

For example, in September 1985, the Plaza Accord among the finance ministers of the Group of Five industrial nations led to drastic realignments in exchange rates and helped stabilize the Japanese trade surplus, though still at very high levels of US\$100-150 billion per year. Thus, regardless of the macroeconomic context (e.g., strong growth and a speculative environment at the end of the 1980s, recession during the 1990s, restructuring in the financial and industrial sectors, improvements since the start of the 2000s), Japanese enterprises have continuously maintained strong competitive advantages over their foreign competitors.

Trade between Japan and China developed significantly starting in the early 1990s. During this decade, Japanese firms faced huge difficulties in the mature economy (e.g., lack of consumption growth, high wages in comparative terms, collapse of stock and real estate prices that badly affected banks and other financial institutions) and delocalized their production to China. China has adopted a positive stance toward FDI since 1992, following the so-called discourse of the South of Deng Xiao Ping, and the country offers very low labor costs. As a consequence, Japan has been the second largest foreign investor in China, after Hong Kong but before the United States and Korea. Goods produced in China by Japanese companies and their local partners then were reimported into Japan or exported to other countries, which led to a widening trade imbalance between Japan and China, increasing from US\$5.9 billion in 1990 to US\$24.4 billion in 2000 and US\$28.8 billion in 2005 .

However, by the beginning of the 2000s, the strategies of Japanese firms toward China changed dramatically (Jaussaud et al., 2009), moving from pure delocalization and reexport to developing sales and market shares in China, a fast growing market with huge potential. In addition, sophisticated parts and components of goods assembled in China are still often 
manufactured in Japan, which has led to a sharp increase of exports from Japan to China and may result in the stabilization or even reduction of the Japanese trade deficit (see Figure 2).

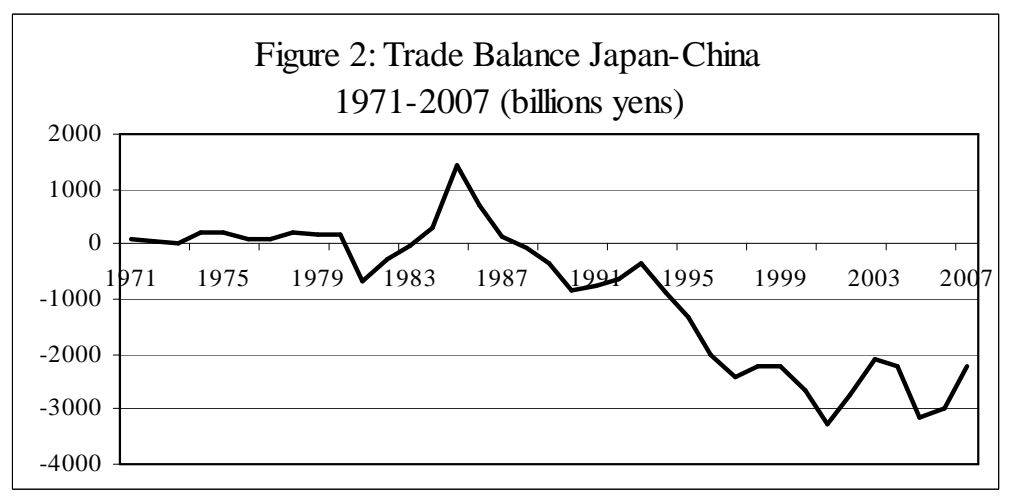

Japanese exports to the United States increased a lot during the 1980s but only very slowly since then; in current terms, exports by Japan to the United States amounted to 7,118 billion yen in 1980, 13,056 billion yen in 1990, 15,536 billion yen in 2000, 14,805 billion yen in 2005 , and 16,896 billion yen in $2007^{3}$. In contrast, exports to China stagnated during the 1980s and then exploded; they amounted to 1,141 billion yen in 1980, 884 in 1990, 3,274 in $2000,8,837$ in 2005 , and 12,838 in 2007.

Figures 3.1 and 3.2 show the evolution of exports to China and the United States, respectively, in volume and thus underline the increasing trends in exports to China but not to the United States.

\footnotetext{
${ }^{3}$ see the Appendix for data sources.
} 

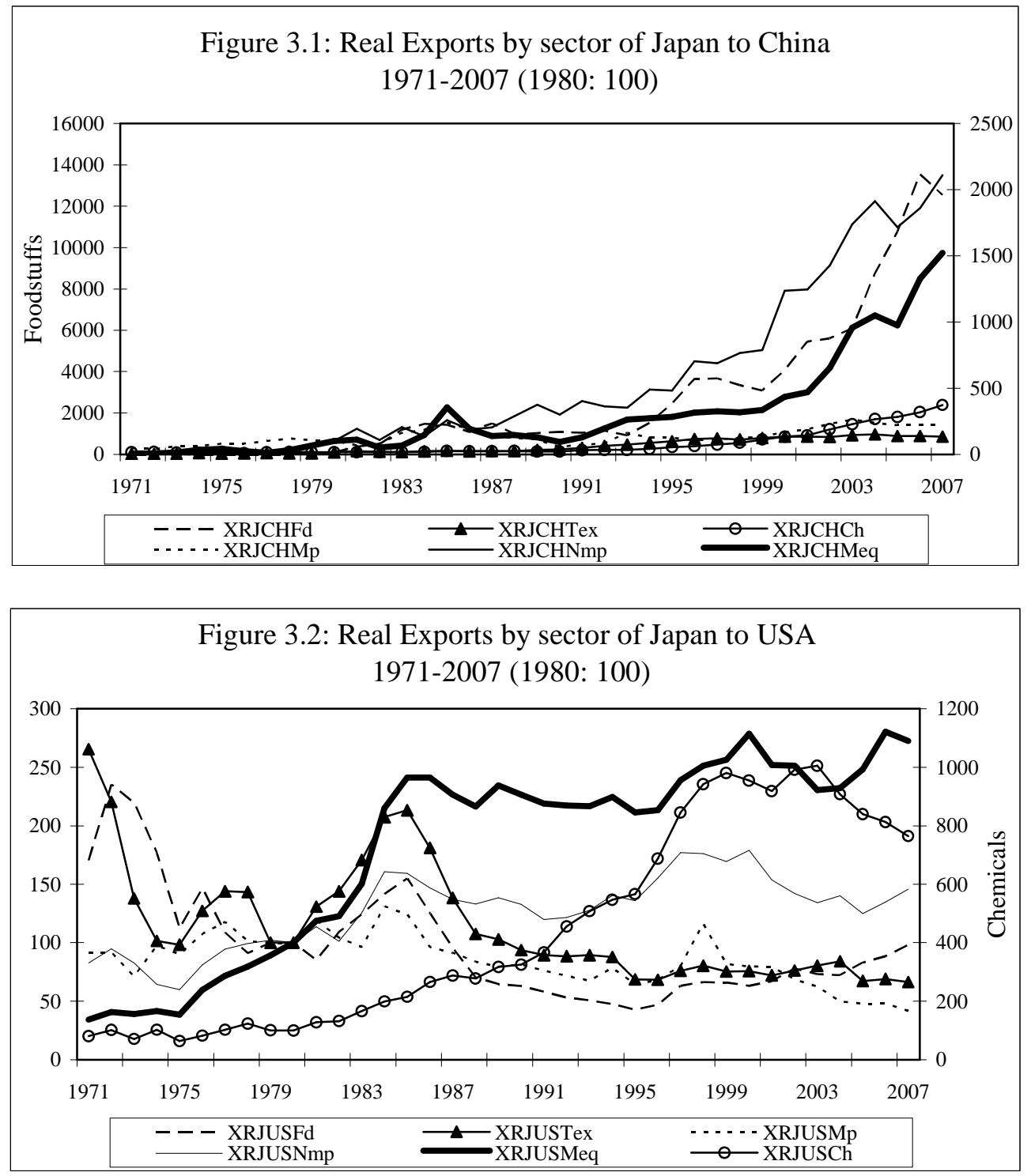

Notes: XJCHaa $=$ exports of Japan to China in the a product category; XJUSaa = exports of Japan to the United States for the same category. Fd =food, Tex = textile, Ch = chemicals, Nmp = non-metal products, $M p$ = metal products, and Meq = machinery and equipments. See the Appendix for data sources.

Japan does not depend as heavily on international trade as other major developed nations. Exports amounted 13.1\% of its gross domestic product (GDP) in 2004, compared with $7.5 \%$ for the United States, $16.7 \%$ for France, and $26.8 \%$ for Germany, two members of the European Union. In 2006, Japanese exported 14.24\% of its GDP yet still enjoys a huge trade imbalance, largely because its exports mainly consist of sophisticated manufactured goods. International trade therefore has a significant effect on Japanese growth and its economic situation. Figures 4.1 and 4.2 summarize some shifts in the export structure, showing the sectoral contributions of total exports by Japan to China and the United States, 
respectively. Machinery and equipment are dominant in exports to both countries, but the contribution of textiles has decreased as other Asian countries, including China, have become major competitors.
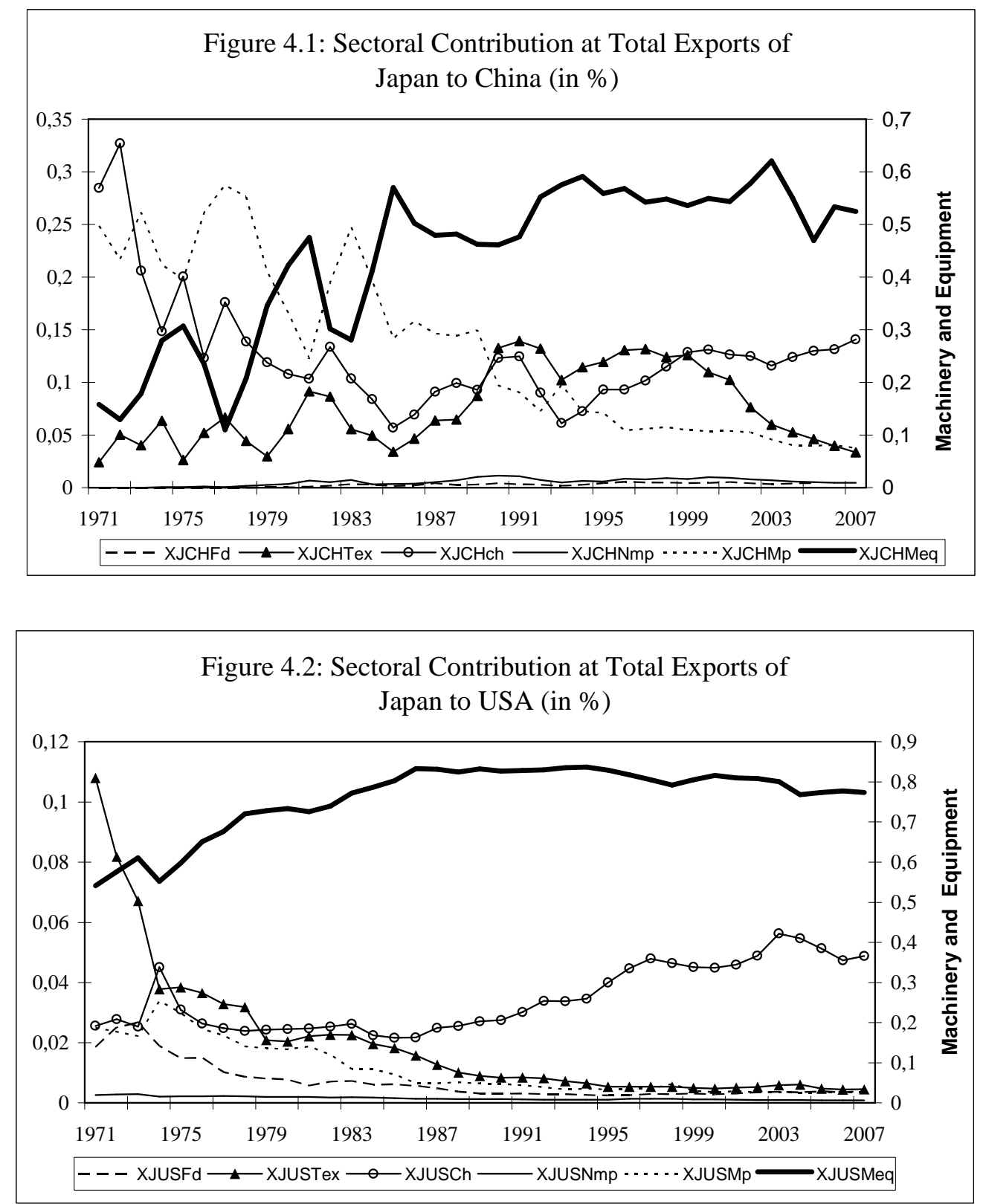

\section{Real yen exchange rates by sectors}

With regard to exports, real exchange rate evolution derives from nominal exchange rate fluctuations and variations in prices, both domestic (in the buying country) and export. 
Export prices also depend on exporter decisions, which represent attempts to adapt to adverse or advantageous nominal exchange rate fluctuations and competitive environments.

\subsection{Japanese exchange rate policy}

In Figures 5.1 and 5.2, we illustrate the Japanese exchange rate policy during the period under investigation. Recall that insofar Chinese authorities chose to anchor the $\mathrm{RMB}$ in the American currency, every fluctuation in dollar/yen parity affects RMB/yen parity. These figures clearly show the drop of the U.S. dollar in 1971 and then again in 19761977, when the former fixed exchange rate system around the U.S. dollar collapsed. From 1981-1985, the effects of the American policy of a strong U.S. dollar under the Reagan Administration are obvious. During that short period, trade imbalances in favor of Japan exploded, particularly toward the United States, causing the yen to be regarded as undervalued, just as the Chinese RMB is regarded today. The Plaza Accord in September 1985 represented a response to this situation that, by coordinating interest rates and exchange rate policies, aimed to and resulted in a drastic realignment of exchange rates and a particularly sharp appreciation of the yen against the U.S. dollar (42\% within one year).
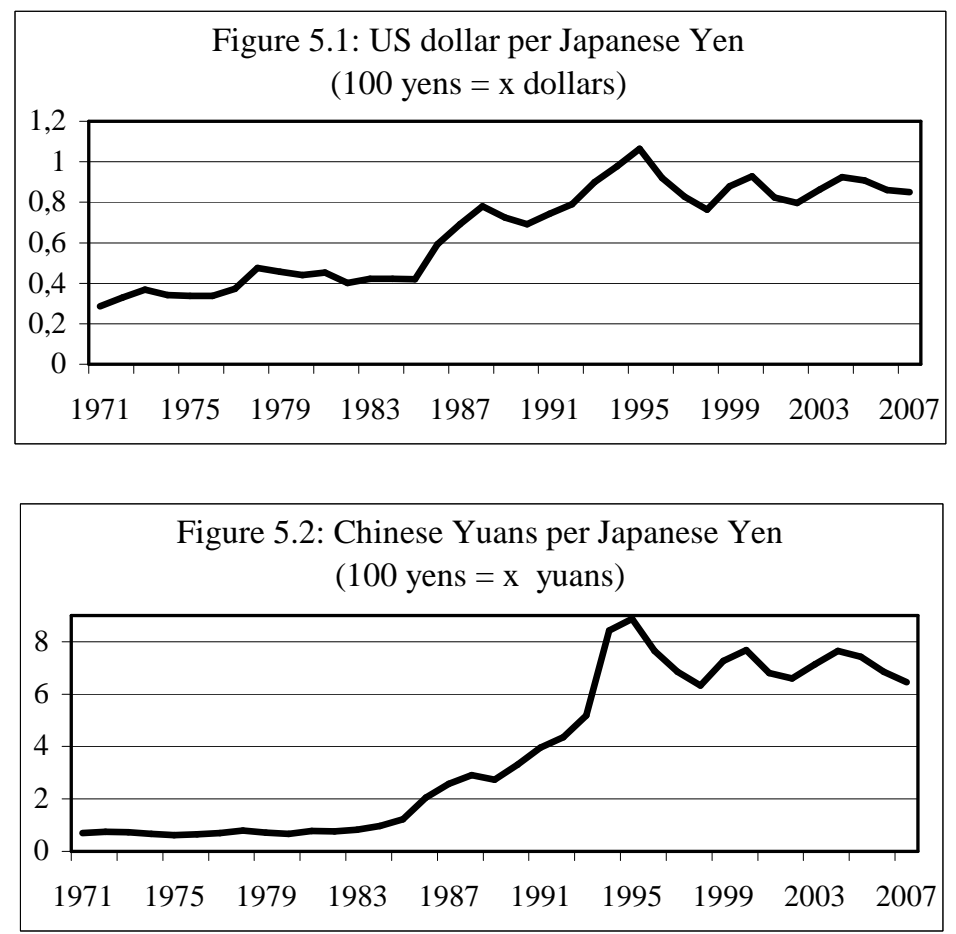
Since then, Japanese authorities, through interest rate manipulations and large-scale intervention in foreign exchange markets, have tried to avoid allowing the yen to appreciate too much in comparison with the dollar, because this shift would harm Japanese exporters, which are also the country's major manufacturers. For example, in 1988-1989, 1993-1995, and 2003-2004, it appeared that the Japanese economy was recovering, and an appreciating yen became a significant concern. Japanese authorities also want to avoid an overly sharp depreciation of the yen, because it would fuel too many Japanese exports to the United States and perhaps trigger a renewed trade dispute, as occurred in 1997-1998. In those years, the Japanese financial system appeared so badly affected that confidence in the Japanese economy and currency vanished.

\subsection{Real exchange rates fluctuations}

To characterize the behavior of real exchange rates, we distinguish the trend and the volatility of real exchange rates for different sectors.

Equation 1 reflects the real exchange rate of the $j$ sector between Japan and the foreign partner, whether China or the United States:

$$
R_{j}=\frac{N \cdot P_{X}^{j}}{P^{*}},
$$

where $P_{X}^{j}$ and $P^{*}$ are the Japanese export price indexes of the $j$ sectors and the domestic product price indexes in China (consumer prices) and the United States (wholesale prices), respectively, and $\mathrm{N}$ the nominal exchange rate of the Japanese yen against the RNB and the US dollar. An increase in $R_{j}$ reflects a real appreciation of the yen. 

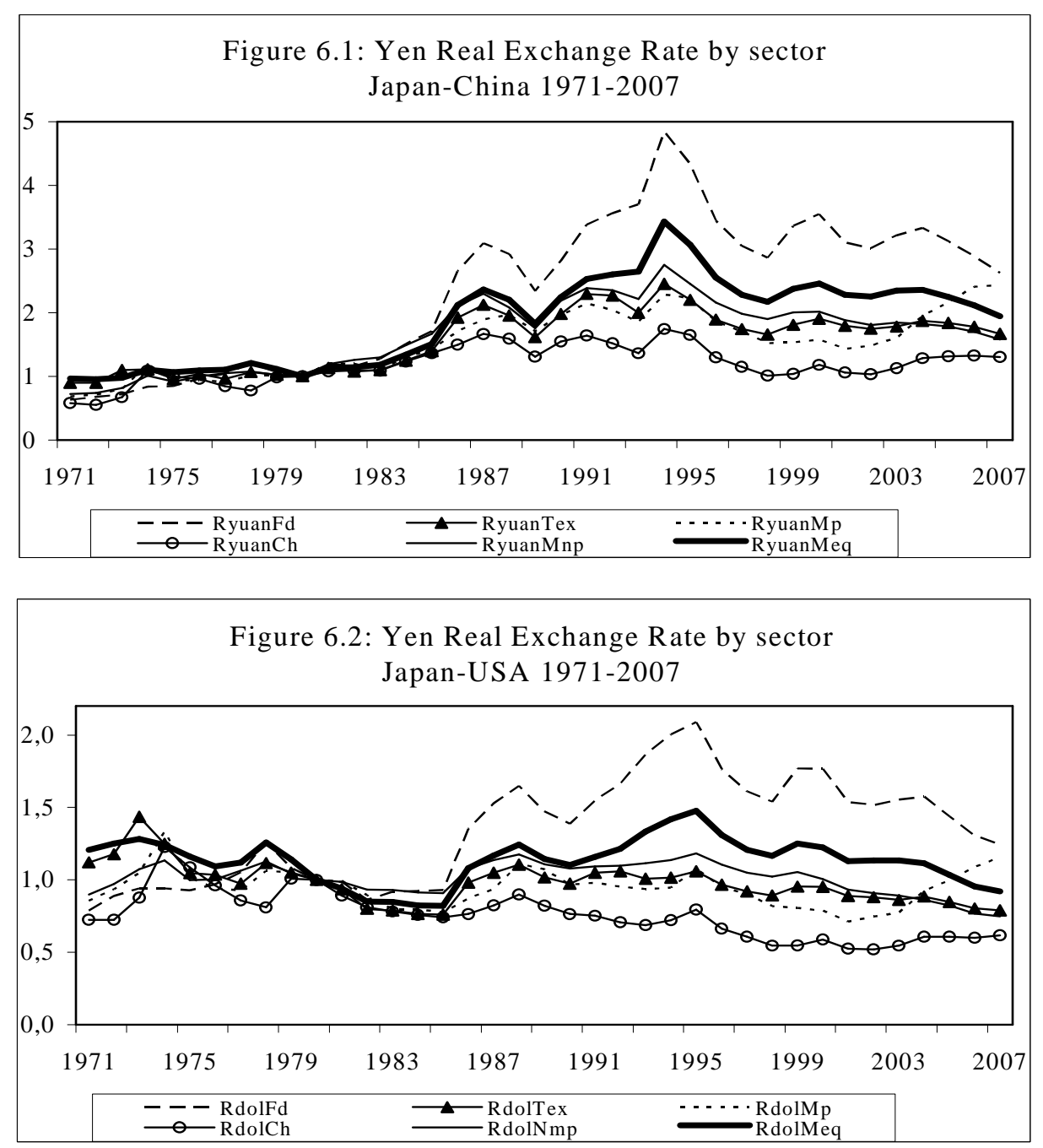

For trade with China, it appears at first glance that the real exchange rate appreciated from the 1970s until 1995, then depreciated a little bit and eventually stabilized. Toward the United States, the trend appears downward until 1985 and upward until 1995 (except for chemicals), after which it eventually stabilized. However, as Figures 6.1 and 6.2 reveal, the real exchange rate differs from sector to sector, possibly to a great extent. These trends of the real exchange rates follow the dispersion of real exchange rates after the Plaza Accord, after which industries took different approaches to lowering their export prices. From 1990 to 1995, "the most significant price declines occurred in chemicals (28 percent), textiles (25 percent), and metals (24 percent)" (Kligaard, 1996 p.2). For example, Japanese firms in the machinery and equipment sector (e.g., car manufacturers, machine-tool builders) have monitored their prices to avoid challenges to their margins, possibly because they offer unique and innovative products, unlike those available in the destination country. Differentiation is more difficult in the field of chemicals, for example, which may explain the greater pressure 
on prices, which leads to more stable or even decreasing real exchange rates. As Parson and Sato (2008) state "In a world of imperfect competition and market segmentation, exporters can differentiate the selling prices across different markets" ( $\mathrm{p} 175)$.

The volatility of real exchange rate may be considered as an indicator of exchange rate uncertainty. Because we address annual data, in order to measure this volatility we proceed in two steps. Firstly, we calculate quarterly volatilities, following two procedures, a moving standard deviation and an ARCH model.

* We calculate a moving standard deviation (noted MSDR) of the growth rate of the sectoral quarterly real exchange rate $\left(\operatorname{denoted} R_{j}^{Q}\right)$ :

$$
\operatorname{MSDR}_{Q t}=\left[(1 / m) \sum_{i=1}^{m}\left(\ln R_{j, t+i-1}^{Q}-\ln R_{j, t+i-2}^{Q}\right)^{2}\right]^{1 / 2},
$$

where $m$ is the order of the moving average, or the window width, and $\ln$ represents the natural logarithm. In our estimations, $m$ equals eight quarters (two years), a standard measure in the literature.

** The second measure is the conditional standard deviation of the first difference of the $\log$ of the exchange rate (noted CSDR). We use the ARCH (Autoregressive Conditional Heteroskedasticity) model suggested by Engle (1982, 2001), completed by a GARCH (Generalized ARCH) model proposed by Bollerslev (1986), which extends the ARCH model to allow the conditional variance (noted $h_{t}$ ) to be an ARMA process. By deriving residuals $\varepsilon_{t}$ from an underlying process, ${ }^{4}$ for the information set $\Psi$, a $\left.\operatorname{GARCH}\right)(p, q)$ process is given by $\varepsilon_{t} / \Psi_{t-1} \sim N\left(0, h_{t}\right)$ with the conditional autoregressive variance specified as

$$
h_{t}=\delta+\sum_{i=1}^{q} \alpha_{i} \cdot \varepsilon_{t-1}^{2}+\sum_{j=1}^{p} \beta_{j} \cdot h_{t-1}
$$

$C S D R=\sqrt{h}$ represents the conditional standard deviation, i.e., the volatility. $\delta>0, \alpha \geq 0$ and $\beta \geq 0$ are imposed to ensure that the conditional variance $\left(h_{t}\right)$ is positive. The unconditional expected variance exists when the process is covariance stationary, i.e., $\sum \alpha_{i}+\sum \beta_{i}<1$

\footnotetext{
${ }^{4}$ If $r_{t}$ is equal to $\ln \left(R_{t}^{Q} / R_{t-1}^{Q}\right)$, we have $r_{t}=\mu+\varepsilon_{t}$ with $\mu$ the mean $r_{t}$ conditional on past information $\left(\Psi_{t-1}\right)$.
} 
Secondly, we calculate the annual average of the quarterly standard deviation (denoted $\left.\sigma_{R}\right)$ :

$$
\sigma_{R}=(1 / 4)\left(S D R_{Q 1}+S D R_{Q 2}+S D R_{Q 3}+S D R_{Q 4}\right)
$$

where SDR represents alternatively $M S D R$ and $C S D R$.

In figures $7-1$ to $7-6$ and $8-1$ to $8-6$, we present the charts of volatilities measured by moving average standard deviation $(M S D R)$ and conditional standard deviation ${ }^{5}$ (CSDR) for the real exchange rate of the yen/yuan and the yen/dollar. Note that the findings presented in Annex show that the ARCH specifications do not give always satisfactory results, taking into account the frequency of data (quarterly data). So, we consider with caution certain ARCH/GARCH specifications. Consequently, in our comments the estimates results with the $M S D R$ will be privileged, even if in many cases $M S D R$ and ARCH measures lead to similar conclusions.

\footnotetext{
${ }^{5}$ To start, we estimated $\operatorname{GARCH}(1,1)$ models for all real exchange rates. The estimation was performed by QMLE (Quasi-Maximum Likelihood Estimation), using the optimization algorithm of BERNDT et al. (1974, BHHH). ${ }^{5}$ When no significant GARCH effect appears, we estimate ARCH and EGARCH (exponential GARCH) models. Finally we adopt the model which offers the best estimates. See detailed results in annex.
} 

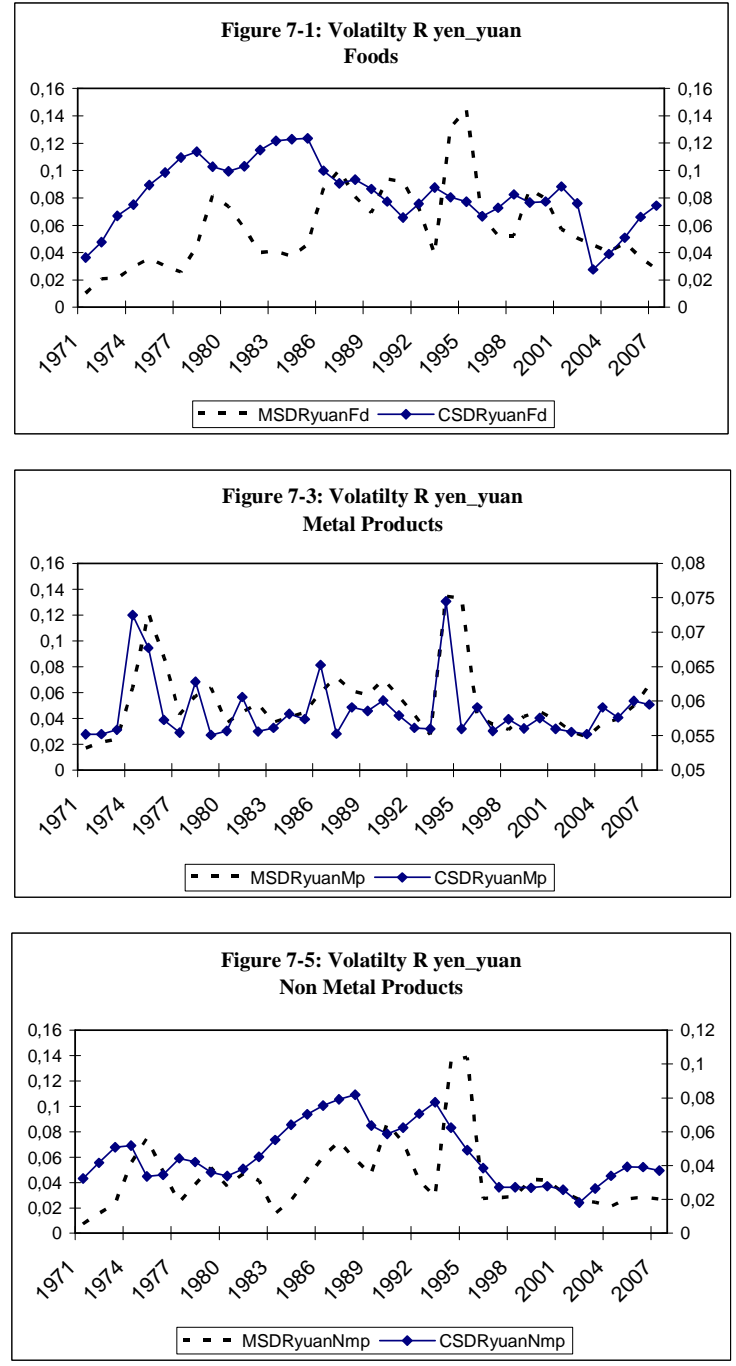
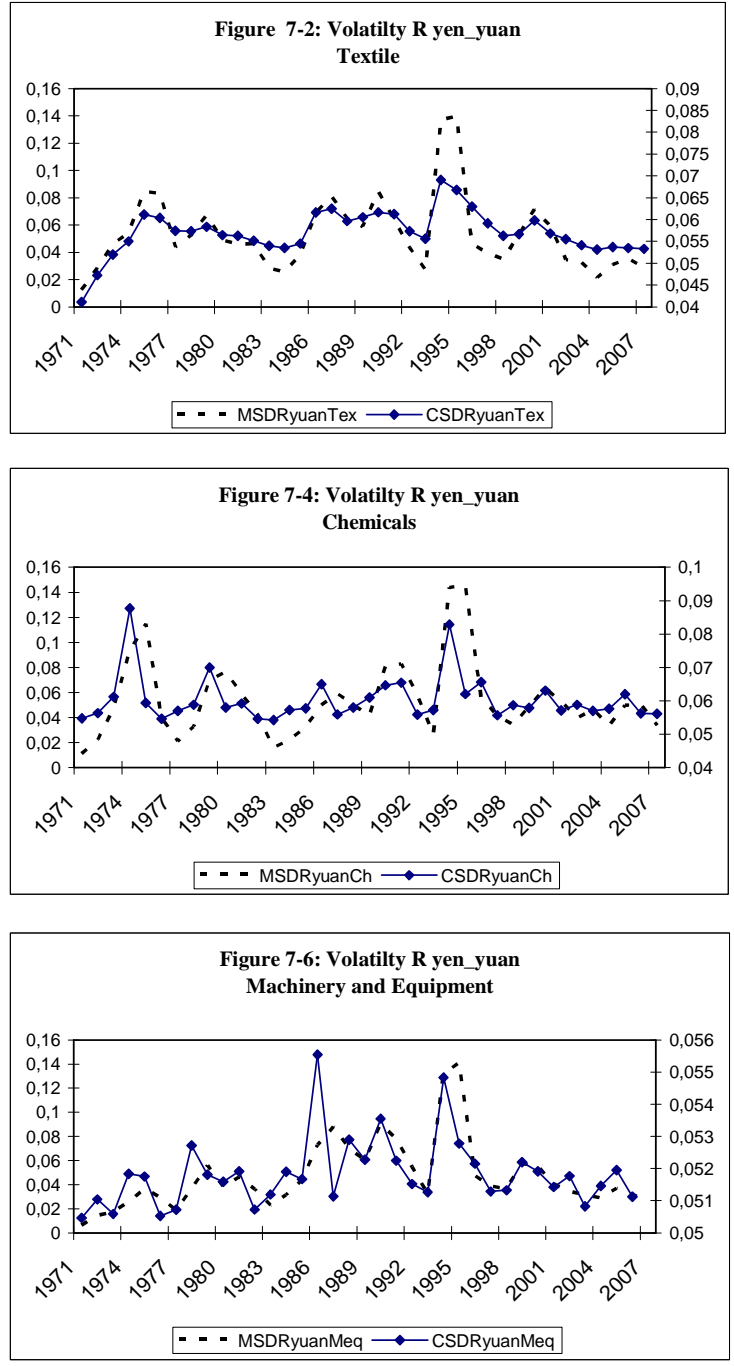

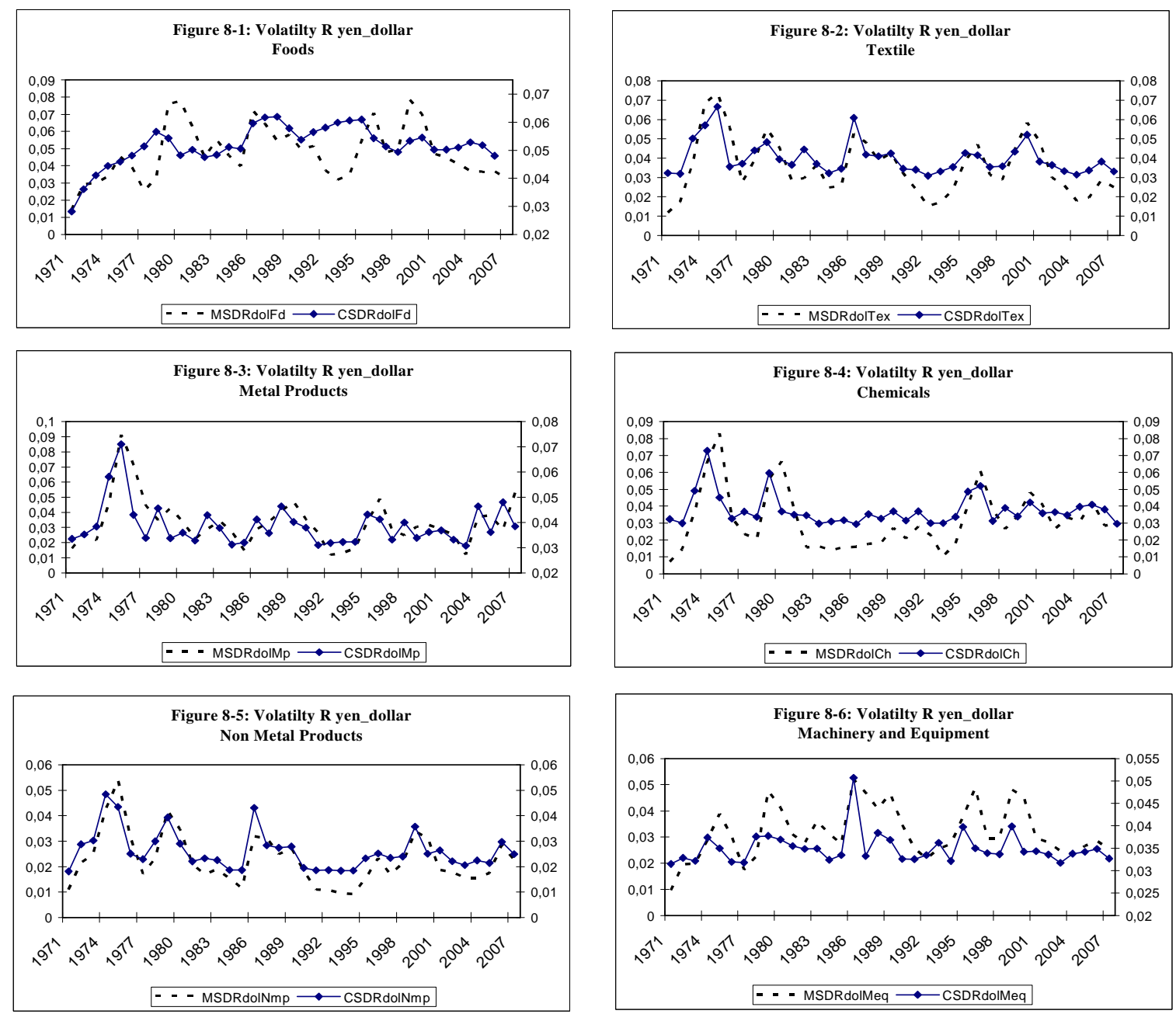

The volatility of the real exchange rates (Figures 7.1 to 7.6 and 8.1 to 8.6) differs a lot in various time periods and from sector to sector, particularly in U.S. trade. This volatility results from both nominal exchange rate volatility and the export price policies of Japanese exporters.

Because it may affect many exports, we include it in our export model.

\section{Export model}

We adopt an imperfect substitute model, in which domestic exports and goods produced abroad offer imperfect substitutes. ${ }^{6}$ Furthermore, we assume that exports are

\footnotetext{
${ }^{6}$ See Goldstein and Kahn (1985, p. 1044) for a discussion of this model; see Klaassen (2004) for an application to the bilateral U.S. exports to other G7 countries.
} 
determined by supply and demand factors. We focus on real exports, that is, nominal exports expressed in domestic currency, deflated by export prices. ${ }^{7}$

On the demand side, real exports depend on a measure of real foreign economic activity (generally GDP, $Y$ ), a relative price, and an indicator of exchange rate volatility $(V)$. The relative price or real exchange rate is defined as $\frac{P_{X}}{P^{*} / N}$, where $N$ represents the nominal exchange rate of the Japanese yen against the RMB and the U.S. dollar, $P^{*}$ is the price of Chinese- or American-produced goods, and $P_{X}$ is the Japanese price of exported goods for the different sectors. Because $P$ is the domestic general price level, as a logarithm, it equals $\log \left(\left(P_{X} / P\right) \cdot\left(P \cdot N / P^{*}\right)\right)=p_{x}+r$, where $r=\log \left(P \cdot N / P^{*}\right)$ is the real (logarithm of the) exchange rate between Japan and China or the United States, and $p_{x}=\log \left(P_{X} / P\right)$ is the domestic relative price (logarithm) of exportable goods.

An increase in the real GDP of an importing country might result in a greater volume of exports, whereas an increase in relative domestic prices, i.e. a real appreciation of the Yen, should reduce the level of real exports. If a risk-adverse importer makes decisions based on relative prices, greater volatility of exchange rates, which implies greater uncertainty, should reduce the demand for exports.

The quantity of Japanese exports demanded by China or the United States thus may be expressed as

$$
x^{d}=x^{d}\left(y, p_{x}+r, v\right),
$$

where all variables are expressed in logarithms, $\left.\partial x^{d} / \partial y\right\rangle 0, \partial x^{d} / \partial r\left\langle 0\right.$, and $\partial x^{d} / \partial v\langle 0$.

On the supply side, the traditional model includes only the price of exports relative to that of domestic products as a determinant of real exports $\left(P_{X} / P\right.$, where $P_{X}$ indicates export prices and $P$ reflects domestic prices) and an indicator of exchange rate uncertainty. The impact of exchange rate volatility is ambiguous from a theoretical point of view. In traditional models, uncertainty about exchange rates translates into uncertainty about future export receipts in domestic currency. Therefore, "by reducing sales, both expected profits and the variance of profits decline, but expected utility increases" (Côté, 1994). More recent literature posits that changes in exchange rates represent not only a risk but also opportunities to make profits (De Grauwe, 1988, 1994). When domestic currency depreciates, prices measured in this currency should rise (i.e., the firm is a price taker and sells its products in foreign

\footnotetext{
${ }^{7}$ We find no data of bilateral export prices. See the Appendix for more details.
} 
currency), which should favor the expected profits (Rey, 2006). The production and export supply thus increase if the firm can adjust one or more factors of its production. We designate the supply of Japanese exports as follows:

$$
x^{s}=x^{s}\left(p_{x}, v\right),
$$

where all variables are expressed in logarithms, and $\left.\partial x^{s} / \partial\left(p_{x}\right)\right\rangle 0$ and $\partial x^{s} / \partial v$ may be negative or positive. The market for Japanese exports is in equilibrium if

$$
x=x^{s}=x^{d}
$$

Solving Equations 4-6 for $p_{x}$ yields

$$
x=x(y, r, v),
$$

where $\partial x / \partial v$ may be negative or positive.

As we aim to investigate the long run relationship between real yen exchange rate fluctuations, external demand and Japanese exports, although the two countries of destination show very different contexts, we have decided to use the same export model for both. At first sight, this may appear to be surprising, as we recognize that the determinants of the exchanges of Japan with regards to these two countries are clearly different. However, such differences will fully translate in differences in elasticities, for each industry, as regards to China and the USA, while referring to the same export model provides greater parsimony.

\section{Empirical analysis}

To apply a cointegration technique, we must first determine the order of integration of each variable. We gather data at an annual frequency during the period 1971-2005 and transform all variables to logarithm form $(L n)$. Thus, $L n G D P$ is the log of Chinese/American GDP, $\operatorname{LnX}$ is the log of sectoral Japanese real exports, $\operatorname{LnR}$ is the log of bilateral real exchange rates, and $\operatorname{LnV}$ is the $\log$ of the volatilities of real exchange rates.

Because the presence of breaks in the variables can render the statistical results invalid, for not only the unit root tests but also the cointegration tests, we retain tests with the breaks developed by Saikkonen and Lütkepohl (2000, 2002).

\subsection{Unit root tests}

In order to examine the statistical properties of the series, we use unit root tests, specifically, the augmented Dickey-Fuller (ADF) test and the Saikkonen and Lütkepohl test 
(hereafter, SL), which take into account the effects of unknown structural changes in the data. In addition, both Saikkonen and Lütkepohl (2002) and Lanne et al. (2002) posit that a shift may spread over several periods rather than being restricted to a single period (Lütkepohl, 2004). The tests we use enable us to examine the null hypothesis of a unit root based on the following general specification:

$$
X_{t}=\mu_{0}+\mu_{1} \cdot t+f_{t}(\theta)^{\prime} \gamma+z_{t},
$$

where $\theta$ and $\gamma$ are unknown parameters, $t$ is the time trend, the error term $z$ is generated by an $A R(p)$ process, and $f_{t}(\theta)^{\prime} \gamma$ is the shift function, which depends on $\theta$ and the regime shift date $T_{B}$. We consider three shift functions:

1. Based on a simple shift dummy,

$$
f_{t}^{1}=d_{1, t}=\left\{\begin{array}{ll}
0, & t<T_{B} \\
1, & t \geq T_{B}
\end{array} .\right.
$$

2. Based on the exponential distribution function, which allows for a nonlinear gradual shift to a new level starting at time $T_{B}$,

$$
f_{t}^{2}(\theta)=\left\{\begin{array}{ll}
0, & t<T_{B} \\
1-\exp \left[-\theta\left(t-T_{B}+1\right)\right], & t \geq T_{B}
\end{array} .\right.
$$

3. A rational function in the lag operator applied to a shift dummy,

$$
f_{t}^{3}(\theta)=\left[\begin{array}{c}
\frac{d_{1, t}}{1-\theta L} \\
\frac{d_{1, t-1}}{1-\theta L}
\end{array}\right]
$$

We first estimate the deterministic term with generalized least squares (GLS), ${ }^{8}$ then apply an ADF test to the adjusted data, which include the series obtained by subtracting them from the original series. ${ }^{9}$ Following the data observations (Figures 3.1, 3.2), we retain a linear trend for GDP and the export series. Tables 1 and 2 summarize the results from the ADF and SL tests. In most cases, the ADF and SL tests diverge, which confirms that the regime shifts are significant.

\footnotetext{
${ }^{8} T_{B}$ corresponds to the date at which GLS objective function is minimized.

${ }^{9}$ The adjusted series are $\hat{X}_{t}=X_{t}-\hat{\mu}_{0}+\hat{\mu}_{1} \cdot t+f_{t}(\hat{\theta})^{\prime} \hat{\gamma}$.
} 
When we consider the three different SL tests, we find support for the stationary hypothesis in only two cases for the Japan-China relationship (metal products and material equipment) and five cases for the relationship between Japan and the United States (U.S. GDP, real exchange rates calculated with metal product and chemical prices, and real exchange rate volatilities with food and textile prices). In the other cases, the tests either conclude at a random walk or do not permit a clear conclusion. In the latter case, we consider these variables as non stationary. 
Table 1: Unit root tests Japan-China 1971-2007

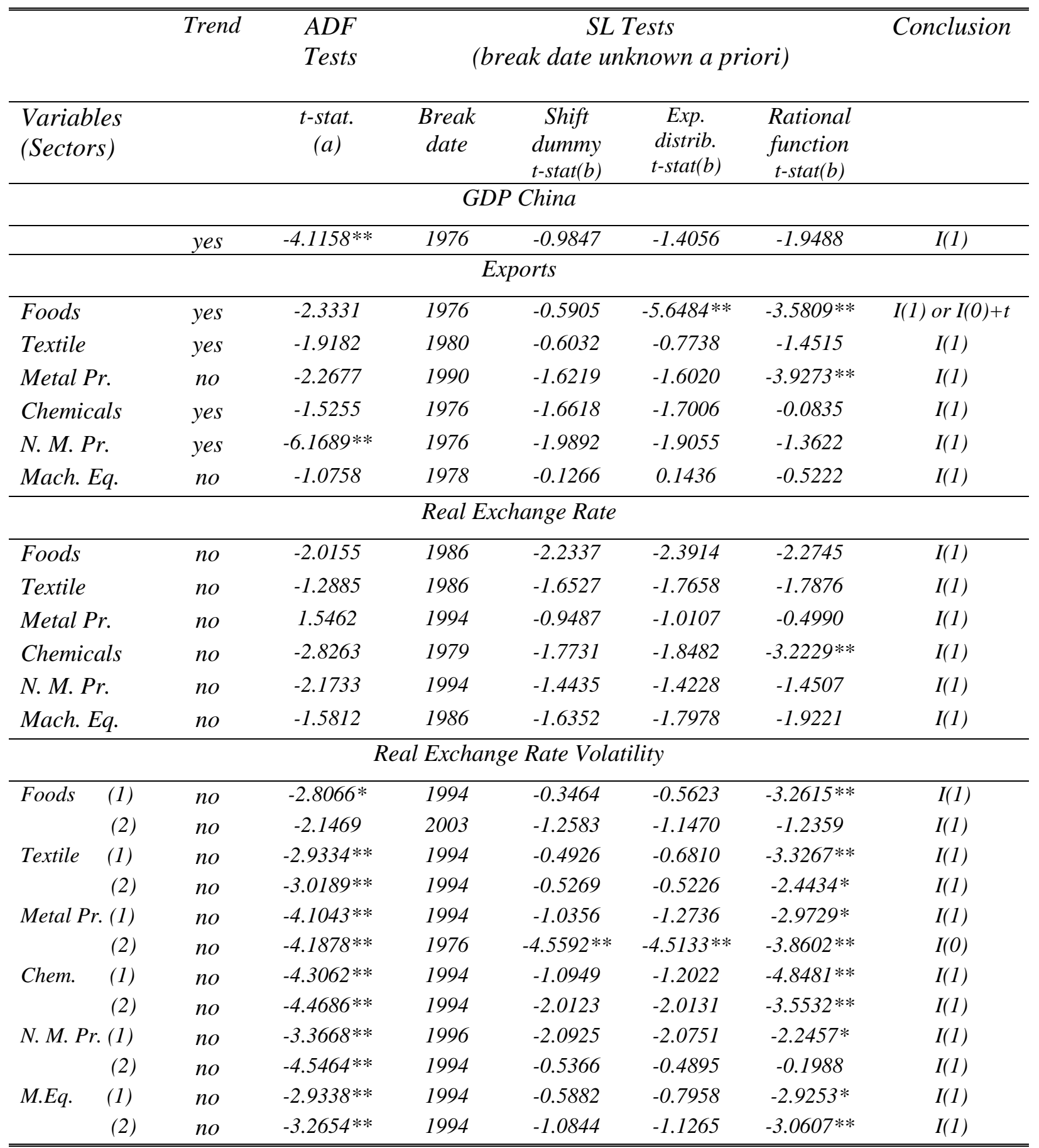

*Significant at 10\% level. **Significant at 5\% level. (1) MSDR; (2) CSDR

(a)For the ADF test, the lags are determined by the Schwartz criterion. Critical values extracted from Davidson and MacKinnon (1993) for the 1\%, 5\%, and 10\% levels are, respectively, -3.96, -3.41, and -3.13 for the model with trend and $-3.43,-2.86$, and -2.57 for the model without trend.

(b) Critical values from Lanne et al. (2002) for the 1\%, 5\%, and 10\% levels are, respectively, $-3.55,-3.03$, and -

2.76 for the model with trend and $-3.48,-2.88$, and -2.58 for the model without trend. 
Table 2: Unit root tests Japan-United States 1971-2007

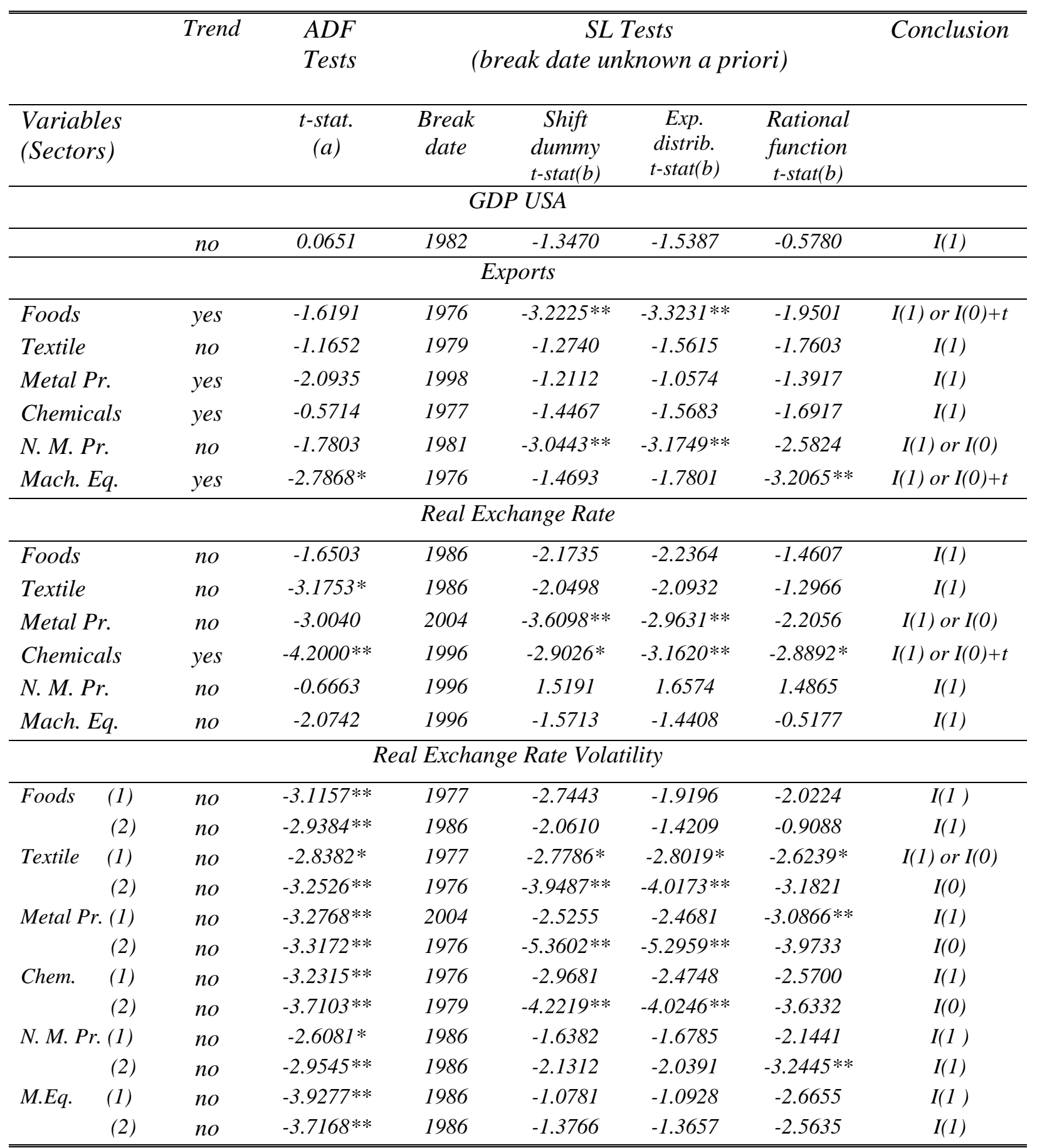

*Significant at 10\% level. **Significant at 5\% level. (1) MSDR; (2) CSDR

(a)For the ADF test, the lags are determined by the Schwartz criterion. Critical values extracted from Davidson and MacKinnon (1993) for the 1\%, 5\%, and 10\% levels are, respectively, -3.96, -3.41, and -3.13 for the model with trend and $-3.43,-2.86$, and -2.57 for the model without trend.

(b) Critical values from Lanne et al. (2002) for the 1\%, 5\%, and 10\% levels are, respectively, $-3.55,-3.03$, and 2.76 for the model with trend and $-3.48,-2.88$, and -2.58 for the model without trend.

Breaks for the real exchange rate differ from sector to sector towards a given country. This possibly results from pricing policies by exporters, which differ as already stated according to sectors and their competitive environment in the country of destination. 


\subsection{Cointegration tests}

In the next step of the analysis, we investigate the number of cointegration relations between series. Following Saikkonen and Lütkepohl (2000), Demetrescu, Lütkepohl, and Saikkonen, (2008), we consider tests for the cointegrating rank of a VAR process when the data generating process (DGP) $y$ has a deterministic component $(\mu)$ and a stochastic component $(x)$, such that $y_{t}=\mu_{t}+x_{t}$, and we assume $\mu$ is generated by a process with a constant, linear trend and shift dummy variables of form $D_{T B}=0$ for $t \leq T_{B}$ and $D_{T B}=1$ for $t>T_{B}$, with $\mu_{t}=\mu_{0}+\mu_{1} \cdot t+\delta . D$, where $t=1,2, \ldots T$. If $\mu$ does not have a linear trend (i.e., $\mu_{1}=0$ ), this term may be dropped. We estimate the parameters of the deterministic part through feasible GLS. Using the estimates, we can adjust $y$ to obtain $\hat{x}_{t}=y_{t}-\hat{\mu}_{0}-\hat{\mu}_{1} . t-\hat{\delta} . D$, and then apply the Johansen LR test for the cointegrating rank to $\hat{x}_{t}$. In other words, the test is based on a reduced rank regression of the system

$$
\Delta \hat{x}_{t}=\Pi \hat{x}_{t-1}+\sum_{i=1}^{p-1} \Gamma_{i} \Delta \hat{x}_{t-i}+u_{t}
$$

The critical values depend on the kind of deterministic term included. We consider a constant $^{1011}$ and shift dummies determined by the unit root tests with break. In Tables 3 and 4, we list the results of various cointegration tests, based on models of order $p=2$. For the Japanese exports to China, we find one cointegration relation for textile and metal product exports, two relations for food and material equipment exports, and three relations for chemicals and non-metal product exports. For Japanese exports to the United States, two cointegration relations emerge for chemicals and non-metal products, and three relations appear in other cases.

\footnotetext{
${ }^{10}$ For space considerations, we do not present the tests with a linear trend orthogonal to the cointegration relations, though they confirm the precedent conclusions.

${ }^{11} \mathrm{We}$ also note that each $I(0)$ variable creates an additional cointegration vector. Tests realized without the $I(0)$ variables (not reported herein) confirm there is always at least one cointegration relationship.
} 
Table 3:Results from Cointegration Tests Japan-China

SL Tests (without trend; $\left.\mu=\mu_{0}+\delta . D\right)(a)$

LR Statistics (lag=1)

\begin{tabular}{|c|c|c|c|c|c|c|}
\hline & & $\begin{aligned} r_{0} & =0 \\
r & >0\end{aligned}$ & $\begin{aligned} r_{0} & =1 \\
r & >1\end{aligned}$ & $\begin{aligned} r_{0} & =2 \\
r & >2\end{aligned}$ & $\begin{aligned} r_{0} & =3 \\
r & >3\end{aligned}$ & \\
\hline C.V. $5 \%$ & Vol.R & 40.07 & 24.16 & 12.26 & 4.13 & Deterministic terms \\
\hline C.V. $10 \%$ & & 37.04 & 21.76 & 10.47 & 2.98 & \\
\hline \multicolumn{7}{|l|}{ Sectors } \\
\hline \multirow[t]{4}{*}{ Foods } & $M S D R$ & $110.54 * *$ & $31.65 * *$ & $14.15^{* *}$ & 0.27 & Constant, D76, D86, D94 \\
\hline & & $(0.000)$ & $(0.004)$ & $(0.023)$ & $(0.663)$ & \\
\hline & $C S D R$ & $108.27 * *$ & $33.57^{* *}$ & 3.24 & 0.20 & Constant, D76, D86, D03 \\
\hline & & $(0.000)$ & $(0.002)$ & $(0.812)$ & $(0.711)$ & \\
\hline \multirow[t]{4}{*}{ Textile } & $M S D R$ & $77.18^{* *}$ & $30.76^{* *}$ & $12.15^{*}$ & 0.95 & Constant, D76, D80, D86, D94 \\
\hline & & $(0.000)$ & $(0.006)$ & $(0.052)$ & $(0.377)$ & \\
\hline & $C S D R$ & $80.51^{* *}$ & $42.66^{* *}$ & $17.34 * *$ & 0.33 & Constant, D76, D80, D86, D94 \\
\hline & & $(0.000)$ & $(0.000)$ & $(0.006)$ & $(0.626)$ & \\
\hline \multirow[t]{4}{*}{ Metal Prod. } & $M S D R$ & $88.61 * *$ & $23.67 *$ & 6.83 & 0.12 & Constant, D76, D90, D94 \\
\hline & & $(0.000)$ & $(0.058)$ & $(0.347)$ & $(0.788)$ & \\
\hline & $C S D R$ & $97.13^{* *}$ & $38.64 * *$ & 6.73 & 0.07 & Constant, D76, D90, D94 \\
\hline & & $(0.00)$ & $(0.001)$ & $(0.358)$ & $(0.846)$ & \\
\hline \multirow[t]{4}{*}{ Chemicals } & $M S D R$ & $78.91^{* *}$ & 16.83 & 3.92 & 0.06 & Constant, D76, D79, D94 \\
\hline & & $(0.000)$ & $(0.328)$ & $(0.722)$ & $(0.851)$ & \\
\hline & $C S D R$ & $98.49^{* *}$ & $28.24 * *$ & 4.84 & 0.15 & Constant, D76, D79, D94 \\
\hline & & $(0.001)$ & $(0.014)$ & $(0.593)$ & $(0.756)$ & \\
\hline \multirow[t]{4}{*}{ Non Metal Pr. } & $M S D R$ & $81.20^{* *}$ & $25.57 *$ & 5.27 & 0.43 & Constant, D76, D94,D96 \\
\hline & & $(0.000)$ & $(0.032)$ & $(0.535)$ & $(0.574)$ & \\
\hline & $C S D R$ & $94.40^{* *}$ & $46.27^{* *}$ & 3.51 & 0.23 & Constant, D76, D94,D96 \\
\hline & & $(0.000)$ & $(0.000)$ & $(0.777)$ & $(0.693)$ & \\
\hline \multirow[t]{4}{*}{ Mach. Equip. } & $M S D R$ & $81.12^{* *}$ & $29.67 * *$ & $15.29 * *$ & 0.26 & Constant, D76, D78, D86, D94 \\
\hline & & $(0.000)$ & $(0.008)$ & $(0.014)$ & $(0.671)$ & \\
\hline & $C S D R$ & $82.64 * *$ & $34.65 * *$ & $18.37 * *$ & 0.51 & Constant, D76, D78, D86, D94 \\
\hline & & $(0.000)$ & $(0.001)$ & $(0.004)$ & $(0.532)$ & \\
\hline
\end{tabular}

Notes: $H_{0}$ is the null hypothesis; $r$ is the number of cointegration vectors. We compute the SL tests with JMulTi software. P-values in parentheses from Trenkler (2004).

*Rejection of the hypothesis at the .05 level. **Rejection of the hypothesis at the 10 level.

(a) Note that if a trend is orthogonal to the cointegration relations, it is captured by the intercept term. 
Table 4:Results from Cointegration Tests Japan-United States

SL Tests (without trend; $\left.\mu=\mu_{0}+\delta . D\right)(a)$

LR Statistics (lag=1)

\begin{tabular}{|c|c|c|c|c|c|c|}
\hline $\begin{array}{l}H_{0}\left(r_{0}\right): r=r_{0} \\
H_{1}\left(r_{0}\right): r>r_{0}\end{array}$ & & $\begin{array}{l}r_{0}=0 \\
r>0\end{array}$ & $\begin{array}{l}r_{0}=1 \\
r>1\end{array}$ & $\begin{array}{l}r_{0}=2 \\
r>2\end{array}$ & $\begin{array}{l}r_{0}=3 \\
r>3\end{array}$ & \\
\hline C.V. $5 \%$ & Vol.R & 40.07 & 24.16 & 12.26 & 4.13 & Deterministic terms \\
\hline C.V. $10 \%$ & & 37.04 & 21.76 & 10.47 & 2.98 & \\
\hline Sectors & & & & & & \\
\hline \multirow[t]{4}{*}{ Foods } & $M S D R$ & $73.61^{* *}$ & $22.68 *$ & 8.53 & 0.39 & Constant, D77, D76, D82, D86 \\
\hline & & $(0.001)$ & $(0.070)$ & $(0.201)$ & $(0.592)$ & \\
\hline & $C S D R$ & $88.55^{* *}$ & $35.74 * *$ & 9.48 & 0.36 & Constant, D76, D82, D86 \\
\hline & & $(0.000)$ & $(0.001)$ & $(0.144)$ & $(0.610)$ & \\
\hline \multirow[t]{4}{*}{ Textile } & $M S D R$ & $86.15^{* *}$ & $34.48^{* *}$ & $10.39 *$ & 1.81 & Constant, D77, D79, D82, D86 \\
\hline & & $(0.000)$ & $(0.001)$ & $(0.103)$ & $(0.209)$ & \\
\hline & $C S D R$ & $83.64 * *$ & $25.19 * *$ & 7.95 & 0.05 & Constant, D77, D79, D82, D86 \\
\hline & & $(0.000)$ & $(0.037)$ & $(0.244)$ & $(0.872)$ & \\
\hline \multirow[t]{4}{*}{ Metal Prod. } & $M S D R$ & $65.93 * *$ & $24.99 * *$ & $10.8 * 5$ & 0.08 & Constant, D82, D98,D04 \\
\hline & & $(0.000)$ & $(0.039)$ & $(0.087)$ & $(0.833)$ & \\
\hline & $C S D R$ & $57.12^{* *}$ & $24.55^{* *}$ & $13.41 * *$ & 0.70 & Constant, D76, D82, D98 \\
\hline & & $(0.003)$ & $(0.045)$ & $(0.03)$ & $(0.458)$ & \\
\hline \multirow[t]{4}{*}{ Chemicals } & $M S D R$ & $58.14 * *$ & 17.27 & 6.08 & 1.13 & Constant, D76, D82, D96 \\
\hline & & $(0.0002)$ & $(0.299)$ & $(0.432)$ & $(0.333)$ & \\
\hline & $C S D R$ & $60.34 * *$ & $23.34 *$ & 8.68 & 0.68 & Constant, D79, D82, D96 \\
\hline & & $(0.001)$ & $(0.064)$ & $(0.191)$ & $(0.463)$ & \\
\hline \multirow[t]{4}{*}{ Non Metal Pr. } & $M S D R$ & $71.33 * *$ & $27.54 * *$ & 6.03 & 0.10 & Constant, D81, D86, D96 \\
\hline & & $(0.000)$ & $(0.017)$ & $(0.437)$ & $(0.806)$ & \\
\hline & $C S D R$ & $69.53 * *$ & 21.06 & 5.94 & 0.19 & Constant, D81, D86, D96 \\
\hline & & $(0.000)$ & $(0.121)$ & $(0.448)$ & $(0.727)$ & \\
\hline \multirow[t]{4}{*}{ Mach. Equip. } & $M S D R$ & $68.10^{* *}$ & $32.56^{* *}$ & 7.51 & 0.82 & Constant, D76, D82, D86, D96 \\
\hline & & $(0.000)$ & $(0.003)$ & $(0.281)$ & $(0.418)$ & \\
\hline & $C S D R$ & $75.59 * *$ & $21.28^{*}$ & $13.72 * *$ & 2.23 & Constant, D76, D82, D86, D96 \\
\hline & & $(0.000)$ & $(0.113)$ & $(0.028)$ & $(0.159)$ & \\
\hline
\end{tabular}

Notes: $H_{0}$ is the null hypothesis; $r$ is the number of cointegration vectors. We compute the SL tests with JMulTi software. P-values in parentheses from Trenkler (2004).

*Rejection of the hypothesis at the .05 level. **Rejection of the hypothesis at the .10 level.

(a) Note that if a trend is orthogonal to the cointegration relations, it is captured by the intercept term. 


\section{Export equations}

Using the results from Section 5.2, we consider a Vector Error Correction Model (VECM) with a cointegrating rank of 1 . Moreover, we include the shift dummy and trend shift dummy variables in the cointegration relations.

To obtain the normalized equations of real exports, we divide each cointegration vector by the negative of the coefficient for real exports. These equations yield estimates of the long-run equilibrium parameters. Tables 5 and 6 present the normalized equations. A synthesis of results is found in the table 7.

In all cases and for the two destinations, the estimated GDP coefficients are significant and positive. As expected, a real appreciation of the yen has a negative effect on exports. For Japanese exports to China (Table 5), the long-run coefficients are superior to one in absolute value in four cases. However in two cases, textile and non-metal product exports, the coefficients of the real exchange rates are not significant. For Japanese exports to USA (Table 6), we also obtain significant negative signs in four cases and not significant coefficients for Non metal products and Machinery and Equipment exports.

The differences in elasticity towards the real exchange rate from sector to sector derive from differences in competitive environments in the destination country, and differentiation strategies of Japanese exporters, as already mentioned (Porter, 1986; Parsons and Sato, 2008). For Machinery and Equipment, for instance, where differentiation is high on the side of Japanese manufacturers, particularly for sophisticated equipments exported to the USA, the elasticity is low (-0.079), whereas it is high for Chemicals or Textile.

Japanese exports of Machinery and Equipment to the USA being inelastic to real exchange rates fluctuations may explain why some authors (Nagayasu, 2007; Miyao, 2003) fail to find a significant effect of exchange rate on Japanese trade balance and growth: indeed, this sector accounts for 80 percent of Japanese exports to USA.

Japanese exports of textile products to China are relative prices (real exchange rates) inelastic, as the coefficient is low and not statistically significant. Japanese exports of Non Metal Products show no significant effect of real exchange rate fluctuations towards both China and the USA. This may derive from the nature of the products, such as high quality textiles from Japan exported to China, demand not being so much sensitive to price (again, products 
Table 5: Normalized Cointegrating Equations Japan-China

$1971-2007$

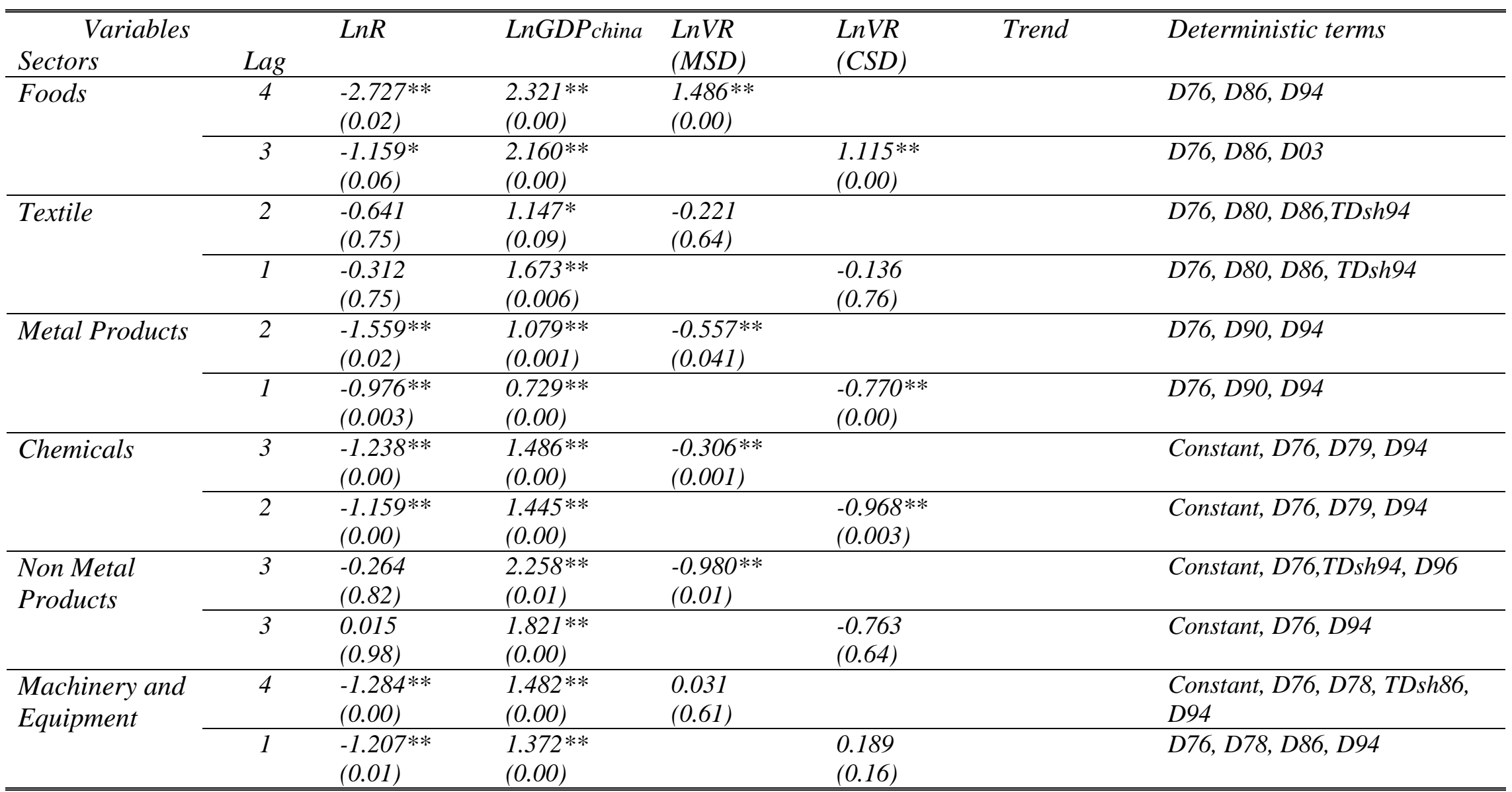

Notes: p-values in parentheses. ** Significant at the 5\% level. * Significant at the $10 \%$ level.

D for Shift Dummy; TDsh for Trend Shift Dummy. 
Table 6: Normalized Cointegrating Equations Japan-USA

$1971-2007$

\begin{tabular}{|c|c|c|c|c|c|c|c|}
\hline $\begin{array}{l}\text { Variables } \\
\text { Sectors }\end{array}$ & Lag & $\operatorname{LnR}$ & LnGDPusa & $\begin{array}{l}\operatorname{LnVR} \\
(M S D)\end{array}$ & $\begin{array}{l}\operatorname{LnVR} \\
(C S D)\end{array}$ & Trend & Deterministic terms \\
\hline \multirow[t]{2}{*}{ Foods } & 1 & $\begin{array}{l}-1.406^{* *} \\
(0.00)\end{array}$ & $\begin{array}{l}1.106 * * \\
(0.00)\end{array}$ & $\begin{array}{l}-0.128 \\
(0.28)\end{array}$ & & & $D 76, D 82, D 86$ \\
\hline & 4 & $\begin{array}{l}-1.795 * * \\
(0.00)\end{array}$ & $\begin{array}{l}0.793 * * \\
(0.00)\end{array}$ & & $\begin{array}{l}-0.439 * * \\
(0.00)\end{array}$ & & $D 76, D 82, D 86$ \\
\hline \multirow[t]{2}{*}{$\begin{array}{l}\text { Textile } \\
\text { (a) }\end{array}$} & 3 & $\begin{array}{l}-2.139 * * \\
(0.00)\end{array}$ & $\begin{array}{l}1.510 * * \\
(0.00)\end{array}$ & $\begin{array}{l}-0.013 \\
(0.69)\end{array}$ & & $\begin{array}{l}-0.089 * * \\
(0.00)\end{array}$ & $D 77, D 79, D 82, D 86$ \\
\hline & 1 & $\begin{array}{l}-2.333 * * \\
(0.00)\end{array}$ & $\begin{array}{l}1.419 * * \\
(0.00)\end{array}$ & & $\begin{array}{l}-0.071 \\
(0.47)\end{array}$ & $\begin{array}{l}-0.092 * * \\
(0.00)\end{array}$ & $D 76, D 79, D 82, D 86$ \\
\hline \multirow[t]{2}{*}{$\begin{array}{l}\text { Metal Products } \\
\text { (a) }\end{array}$} & 2 & $\begin{array}{l}-1.307 * * \\
(0.00)\end{array}$ & $\begin{array}{l}1.194 * * \\
(0.00)\end{array}$ & $\begin{array}{l}-0.082 \\
(0.20) \\
\end{array}$ & & $\begin{array}{l}-0.054 * * \\
(0.00)\end{array}$ & D82, D98, D04 \\
\hline & 4 & $\begin{array}{l}-1.672 * * \\
(0.00)\end{array}$ & $\begin{array}{l}1.168 * * \\
(0.00)\end{array}$ & & $\begin{array}{l}-0.240 * \\
(0.07)\end{array}$ & $\begin{array}{l}-0.066 * * \\
(0.00)\end{array}$ & $D 82, D 98, D 04$ \\
\hline \multirow[t]{2}{*}{ Chemicals } & 4 & $\begin{array}{l}-1.707 * * \\
(0.00)\end{array}$ & $\begin{array}{l}1.751 * * \\
(0.00)\end{array}$ & $\begin{array}{l}-0.571 * * \\
(0.00)\end{array}$ & & & Constant, D76, D77, D82, D96 \\
\hline & 4 & $\begin{array}{l}-1.263 * * \\
(0.03)\end{array}$ & $\begin{array}{l}3.016 * * \\
(0.00)\end{array}$ & & $\begin{array}{l}-1.650 * * \\
(0.03)\end{array}$ & & Constant, D77, D82, D95, D96 \\
\hline \multirow{2}{*}{$\begin{array}{l}\text { Non Metal } \\
\text { Products } \\
\text { (a) }\end{array}$} & 3 & $\begin{array}{l}0.113 \\
(0.39) \\
\end{array}$ & $\begin{array}{l}1.148 * * \\
(0.00)\end{array}$ & $\begin{array}{l}-0.019 \\
(0.72)\end{array}$ & & $\begin{array}{l}-0.009 * * \\
(0.01)\end{array}$ & $D 81, D 82, D 96$ \\
\hline & 3 & $\begin{array}{l}0.055 \\
(0.66)\end{array}$ & $\begin{array}{l}0.859 * * \\
(0.00)\end{array}$ & & $\begin{array}{l}-0.304 * * \\
(0.00)\end{array}$ & $\begin{array}{l}-0.014 * * \\
(0.00)\end{array}$ & $D 81, D 82, D 86$ \\
\hline \multirow[t]{2}{*}{$\begin{array}{l}\text { Machinery and } \\
\text { Equipment }\end{array}$} & 3 & $\begin{array}{l}-0.079 \\
(0.79)\end{array}$ & $\begin{array}{l}1.392 * * \\
(0.02)\end{array}$ & $\begin{array}{l}-0.292 \\
(0.14)\end{array}$ & & & $\begin{array}{l}\text { Constant, D76, D82, TDsh86, } \\
\text { D96 }\end{array}$ \\
\hline & 4 & $\begin{array}{l}-0.145 \\
(0.50)\end{array}$ & $\begin{array}{l}0.864 * * \\
(0.02)\end{array}$ & & $\begin{array}{l}-0.223 \\
(0.58)\end{array}$ & & D76,D82, TDsh86, D96 \\
\hline
\end{tabular}

Notes: p-values in parentheses. ** Significant at the 5\% level. * Significant at the $10 \%$ level.

D for Shift Dummy; TDsh for Trend Shift Dummy.

(a)To save space we don't present results of cointegration tests with linear trend. But we can note that in all cases, we obtain at least one cointegration relation. 
differentiation effect). It may also derive from intra-group trade, ore more broadly integrated trade, being processed partly in Japan and partly in China, with no short term effect of real exchange rate fluctuations. Additional research is needed on the nature of products which are exported and the context of these exports to better interpret this result.

Looking to the effects of the estimated volatility coefficients are negative in all cases for exports to the USA and 4 cases among 6 for exports to China. We obtain positive and statistically significant coefficients in one case, foods exports, which constitute the exception. For machinery and equipment the coefficients are positive but very weak and not significant $^{12}$.

A positive and statistically significant effect of volatility of the real exchange rate is something that occurs quite often in food markets, possibly as a significant part of exchanges for food products is made of commodities, rather than processed products. The production decisions are made several months in advance compared to marketing decisions, at a time when market conditions are not properly known (Bonroy et al., 2006). Then, recent works emphasize the entry/exit costs and evaluate "real options" to participate or not in exports markets (Franke (1991), Baum et al. (2004). In this approach, exchange rates fluctuations do not represent only a risk, but also opportunities to make a profit (De Grauve, 1988, 1994; Franke, 1991; Baum et al., 2004). In this case, "one view maintains that the capacity to export is tantamount to holding an option and when exchange rate volatility increases, the value of that option also increases, just as it would for any normal option" (McKenzie and Brooks, 1997). ${ }^{13}$

In Table 7, we present a synthesis of the results that enables us to compare the sensibility of exports for all sectors and for the two destinations.

\footnotetext{
${ }^{12}$ If the volatility effect upon exports may be ambiguous, this may be due to the measure of this volatility, realized in two steps. On one side, we retain low frequency data (quarterly) to calculate the standard deviation of real exchange rate variations. On other side, we obtain the annual volatility by an average of quarterly data that smooth series

${ }^{13}$ BAUM et al. show that exporters are also sensitive to the volatility of foreign income. See also, FRANKE, 1991, SERCU and Van HULLE, 1992, SERCU and UPPAL, 2003.
} 
Table 7: Synthesis of Long-Run Effects on Japanese Exports

\begin{tabular}{|c|c|c|c|c|c|c|c|c|}
\hline & & Sectors & Foods & Textile & $\begin{array}{l}\text { Metal } \\
\text { Products }\end{array}$ & Chemicals & $\begin{array}{l}\text { Non-Metal } \\
\text { Products }\end{array}$ & $\begin{array}{l}\text { Machinery } \\
\text { Equipment }\end{array}$ \\
\hline Variables & $\begin{array}{l}\text { Trade } \\
\text { partner }\end{array}$ & $\begin{array}{l}\text { Model } \\
\text { with }\end{array}$ & \multicolumn{6}{|c|}{ Fundamentals } \\
\hline \multirow[t]{4}{*}{$\operatorname{LnR}$} & China & 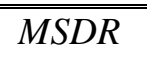 & $<0$ & $<0$ but $N S$ & $<0$ & $<0$ & $<0$ but $N S$ & $<0$ \\
\hline & & $C S D R$ & $<0$ & $<0$ but $N S$ & $<0$ & $<0$ & $>0$ but $N S$ & $<0$ \\
\hline & USA & $M S D R$ & $<0$ & $<0$ & $<0$ & $<0$ & $>0$ but $N S$ & $<0$ but $N S$ \\
\hline & & $C S D R$ & $<0$ & $<0$ & $<0$ & $<0$ & $>0$ but $N S$ & $<0$ but $N S$ \\
\hline \multirow[t]{4}{*}{$L n V R$} & China & $M S D R$ & $>0$ & $<0$ but $N S$ & $<0$ & $<0$ & $<0$ & $>0$ but $N S$ \\
\hline & & $C S D R$ & $>0$ & $<0$ but $N S$ & $<0$ & $<0$ & $<0$ but NS & $>0$ but $N S$ \\
\hline & $U S A$ & $M S D R$ & $<0$ but $N S$ & $<0$ but $N S$ & $<0$ but $N S$ & $<0$ & $<0$ but $N S$ & $<0$ but NS \\
\hline & & $C S D R$ & $<0$ & $<0$ but NS & $<0$ & $<0$ & $<0$ & $<0$ but $N S$ \\
\hline \multirow[t]{4}{*}{$L n G D P$} & China & $M S D R$ & $>0$ & $>0$ & $>0$ & $>0$ & $>0$ & $>0$ \\
\hline & & $C S D R$ & $>0$ & $>0$ & $>0$ & $>0$ & $>0$ & $>0$ \\
\hline & USA & $M S D R$ & $>0$ & $>0$ & $>0$ & $>0$ & $>0$ & $>0$ \\
\hline & & $C S D R$ & $>0$ & $>0$ & $>0$ & $>0$ & $>0$ & $>0$ \\
\hline
\end{tabular}

Notes: NS indicates not significant at the $10 \%$ level.

We can conclude that globally, relative prices fluctuations and exchange rate risk are significant factors affecting bilateral exports from Japan to China and USA. Generally, the signs of the coefficients are conform to the orthodox theory. However, there are some exceptions with significant consequences, such as Machinery and Equipment towards the USA.

In addition to that, we have to check whether the relations are stable or not across the period. Using JMulti software, we might apply break-point, sample-split, and Chow forecast (CF) tests to the full system, including multivariate time-series models. Insofar as we estimate export models with a small sample, we retain only the CF test. The statistics test (e.g., Lütkepohl, 2004) asymptotically follows an F-distribution. The null hypothesis $\left(H_{0}\right)$ reflect the constancy of all coefficients, including the residual covariance matrix, and thus the stability of the model, compared with the alternative that all coefficients vary. We must reject the null hypothesis if the value of the test statistic is large. But as Lütkepohl et al. (2006 p. 22) note, "the actual small sample distributions of the test statistics under $\mathrm{H}_{0}$ may be quite different from the asymptotic $\chi^{2}$ or F-distribution.” Thus, Candelon and Lütkepohl (2001) 
propose using boostrap versions of the Chow test; JMulti calculates the boostrapped p-values to improve small sample properties.

Tables 8 and 9 present the results of the CF tests for the VECM models. The break dates are unknown a priori and determined endogenously. We choose 1,000 replications to construct the boostrapped $p$-values.

For exports to China, the stability hypothesis is rejected for textile and metal products with arch measure of volatility and for Machinery and Equipment exports (two models). Note that this rejection coincides with 1990 as date of break ${ }^{14}$.

Table 8: Chow Forecast Test Japan-China

\begin{tabular}{lccccc}
\hline \hline Sectors & Break date & $\begin{array}{c}\text { Chow } \\
\text { forecast test }\end{array}$ & $\begin{array}{c}\text { Bootstrapped } \\
\text { p-value }\end{array}$ & $\begin{array}{c}\text { Asymptotic } \\
\text { F p-value }\end{array}$ \\
\hline Foods & 1 & 2004 & 0.2276 & 0.3740 & 0.9917 \\
& 2 & 1999 & 0.3111 & 0.2810 & 0.9941 \\
Textile & 1 & 1995 & 0.1654 & 0.8950 & 1.0000 \\
& 2 & 1990 & $116.63^{* *}$ & $0.0001^{* *}$ & $0.0001^{* *}$ \\
Metal Prod. & 1 & 1994 & 0.1647 & 0.9520 & 1.0000 \\
& 2 & 1990 & $94.87^{* *}$ & $0.0001^{* *}$ & $0.0001^{* *}$ \\
Chemicals & 1 & 2000 & 0.2866 & 0.1520 & 0.9947 \\
& 2 & 1995 & 0.3120 & 0.0850 & 0.9965 \\
Non Metal Pr.1 & 1999 & 0.1079 & 0.9910 & 1.0000 \\
& 2 & 1998 & 0.1957 & 0.8840 & 0.9999 \\
Mat. Equip. & 1 & 1990 & $81.04^{* *}$ & $0.0070^{* *}$ & $0.0001^{* *}$ \\
& 2 & 1990 & $69.73^{* *}$ & $0.0460^{* *}$ & $0.0001^{* *}$ \\
\hline \hline
\end{tabular}

(1)MSDR; (2) CSDR

** for reject of the null hypothesis of constant parameters (stability)

\footnotetext{
${ }^{14}$ For Metal Products, the first chosen date break by the model is 1989 . The stability test for this date break gives a similar result.
} 
Table 9: Chow Forecast Test Japan-United States

\begin{tabular}{lccccc}
\hline \hline Sectors & Break date & $\begin{array}{c}\text { Chow } \\
\text { forecast test }\end{array}$ & $\begin{array}{c}\text { Bootstrapped } \\
\text { p-value }\end{array}$ & $\begin{array}{c}\text { Asymptotic } \\
\text { F p-value }\end{array}$ \\
\hline Foods & 1 & 1989 & 38.40 & 0.7280 & 0.1396 \\
& 2 & 2004 & 0.2046 & 0.5050 & 0.9949 \\
Textile & 1 & 2001 & 0.1894 & 0.6240 & 0.9996 \\
& 2 & 1991 & $65.12^{* *}$ & 0.1770 & $0.0002^{* *}$ \\
Metal Prod. & 1 & 1995 & 0.2749 & 0.4330 & 0.9986 \\
& 2 & 2005 & 0.0566 & 0.9900 & 1.0000 \\
Chemicals & 1 & 2006 & 0.1021 & 0.8300 & 0.9964 \\
& 2 & 2006 & 0.2329 & 0.2760 & 0.9620 \\
Non Metal Pr.1 & 2000 & 0.3414 & 0.0860 & 0.9858 \\
& 2 & 2000 & 0.2870 & 0.1500 & 0.9947 \\
Mat. Equip. & 1 & 2001 & 0.1217 & 0.8420 & 1.0000 \\
& 2 & 2005 & 0.1454 & 0.6310 & 0.9970 \\
\hline \hline
\end{tabular}

(1) MSDR; (2) CSDR

$* *$ for reject of the null hypothesis of constant parameters (stability)

For exports to USA, the stability hypothesis may be accepted without ambiguity, except in one case, concerning textile.

\section{Conclusion}

During the period 1971-2007, Japanese exports to China and the United States depended on the real exchange rate and GDP. This result is valid for most sectors and for both geographical destinations. With the exception of Non-Metal Product and Machinery and Equipment exports to the United States on one hand, and Textile and Non Metal Product exports to China on the other hand, a real appreciation of the yen has a negative effect on exports, a finding that confirms the importance of the exchange rate policy of Japan and its trading partners. However, we should keep in mind that $80 \%$ of Japanese exports to the USA are made of Machinery and Equipment, which are inelastic towards the real exchange rate. As a consequence, a real depreciation (versus appreciation) of the yen towards the US dollar may constitute an inappropriate policy when looking for increased (versus reduced) exports to the USA.

A change seems to mark Japan's current exchange rate policy, anyway. Beginning in 2008, the yen rose sharply against the dollar, which traded at less than 100 yen as in 1995 . 
This time, Japanese authorities reacted softly. The Ministry of Finance acknowledged that a strong yen may benefit Japan in the long run, because it reduces the burden of oil and raw material imports, whose prices in dollars were extremely high in $2008^{15}$. In addition, Japanese exporters have developed strong production bases in China and elsewhere, and they may have more flexibility to adapt to a strong yen, though most claim that they would not be able to remain profitable at the 90 yen-US $\$ 1$ level ${ }^{16}$.

In 2009, however, the most worrying concern is on trading partners' GDP effects on Japanese exports. The benefits from positive elasticity in all sectors for export will not be grasped until a significant recovery will occur in China or in the USA, or preferably both.

\section{References}

Bamani-Oskooee, M., Hegerty, S.W., 2009, "The Japanese-U.S. trade Balance and the Yen: Evidence from Industry Data", Japan and the World Economy 21, 161-171.

Berndt, E.K., B.H. Hall, R.E. Hall, Hausman, J.A., 1974, "Estimation Inference in Nonlinear Structural Models," Annals of Economic and Social Measurement, 4, 653-665.

Boltho, A., 1996, “Was Japanese growth Export-Led?”, Oxford Economic Papers , 48, n³, 415-432.

Bollerslev, T., 1986, “Generalized Autoregressive Conditional Heteroskedasticity,” Journal of Econometrics, April, 31:3, 307-327.

Candelon, B., Lütkepohl H., 2001, "Unit Root Tests for Time Series with Level Shifts: A comparison of Different Proposals", Economic Letters 73, 155-160.

Chen, P., Hsiao, C.-Y., 2008, "What Happens to Japan if China Catches a Cold? A Causal Analysis of Chinese Growth and Japanese Growth", Japan and the World Economy 20, 622-638.

Choudhry, T., 2005, "Exchange Rate Volatility and the United States Exports: Evidence from Canada and Japan", Journal of the Japanese and International Economies 19 (March), 51-71.

Côté, A., 1994, "Exchange Rate Volatility and trade: A Survey", Working paper 94-5, Bank of Canada.

Davidson, R., Mac Kinnon, J., 1993, Estimation and Inference in Econometrics, Oxford University Press, London.

\footnotetext{
${ }^{15}$ Nihon Keizai Shimbun, 2008, March 27.

${ }^{16}$ Nihon Keizai Shimbun, 2008, March 18.
} 
Demetrescu, M., Lütkepohl, H., Saikkonen, P., 2008, “Testing for the cointegrating Rank of a Vector Autoregressive Process with Uncertain Deterministic Trend Term”, European University Institute, working paper 2008/24.

Engle, R., 1982, "Autoregressive Conditional Heteroskedasticity with Estimates of the Variance of United Kingdom Inflation,” Econometrica, 50:4, 987-1007.

Engle, R., 2001, "GARCH 101: The Use of ARCH/GARCH Models in Applied Econometrics," Journal of Economic Perspectives 15, 157-168.

Engle, R., 2004, "Risk and Volatility: Econometric Models and Financial Practice", The American Economic Review 94, n³, June, 405-420.

Goldstein, M., Kahn, M. S., 1985, "Income and Price effects in Foreign Trade”, in R.W. Jones and P.B. Kenen (Eds.), Handbook of International Economics, Vol. 2, North-Holland, New York.

de Grauwe, P., 1988, “ Exchange Rate Variability and The Slowdown in Growth of International Trade", IMF Staff Papers 35, n¹, 63-84.

de Grauwe, P., 1994, The Economics of Monetary Integration, Oxford University Press , 2nd edition.

Hatemi-J, A., 2002, "Export Performance and Economic Growth Nexus in Japan : a Boostrap Approach", Japan and the World Economy 14, 25-33.

Jaussaud, J., Mizoguchi, S., Nakamura, H., Schaaper, J., Yamashita, S., 2009, "Control of subsidiaries abroad: a comparison of Japanese and French MNCs in China, Journal of International Management, forthcoming.

Klaassen, F., 2004, "Why is it so difficult to find an effect of exchange rate risk on trade?", Journal of International Money and Finance 23, 817-839.

Klein, L.R., 2000, "International Financial Volatility and Agricultural Commodity Trade: A Primer: Discussion”, American Journal of Agricultural Economics 82, 701-702.

Kligaard, T., 1996, “Coping with the Rising Yen: Japan's Recent Export Experience”, Federal Reserve Bank of New York, Current Issues in Economics and Finance 2, ${ }^{\circ} 1$.

Lanne, M., Lütkepohl, H., Saikkonen, P., 2002, "Comparison of Unit Root Tests for Time Series with Level Shifts”, Journal of Time Series Analysis 23 (November), 667-685.

Lütkepohl, H., 2004, "Recent Advances in Cointegration Analysis", Economics Working Papers ECO2004/12, European University Institute.

Lütkepohl, H., Kratzig, M., Boreiko D., 2006, "VAR Analysis in JMulTi”, mimeo, January, http://www.jmulti.com/download/help/var.pdf. 
Miyao, R., 2003, “The Effects of Yen Depreciation Policy in Japan”, Economic Review 54, $\mathrm{n}^{\circ} 2,114-125$.

Nagayasu, J., 2007, “Empirical Analysis of the Exchange Rate Channel in Japan”, Journal of International Money and Finance 26, 887-904.

Nelson, D. B., 1991, "Conditional heteroskedasticity in Asset Returns: a New Approach", Econometrica, 59, 347-370.

Parsons, C., R., Sato, K., 2008, New Estimates of Exchange Rate Pass-Through in Japanese Exports, International Journal of Finance and Economics, Vol. 13, 174-183.

Porter, M., 1986, "Competition in Global Industries: A Conceptual Framework" in M. Porter (ed.), Competition in Global Industries, Harvard Business School Press, Boston.

Rey, S., 2006, "Effective Exchange rate Volatility and MENA countries' exports to EU", Journal of Economic Development 31, n², 23-54.

Saikkonen, P., Lütkepohl, H., 2000, "Testing for the Cointegrating Rank of a VAR Process with an Intercept", Econometric Theory 16, 373-406.

Saikkonen, P., Lütkepohl, H., 2002, “Testing for a Unit Root in a Time Series with a Level Shift at Unknown Time", Econometric Theory 18, 313-348.

Trenkler, C., 2003, “A New Set of Critical Values for Systems Cointegration Tests with a Prior Adjustment for Deterministic Terms", Economics Bulletin 3(11), 1-9.

\section{Appendix I: Data Source}

Information about exports from Japan to China and the United States come from several editions of the Japan Statistical Yearbook. To obtain the volume of sectoral Japanese exports (real exports), we divide the value series by the price indexes of each sector. However, because of the absence of complete series for export prices, we divide the export values of (1) machinery and equipment by the export prices of general machinery and equipment, (2) non-metal products by the export prices of other manufacturing industry products, and (3) food products by the wholesale prices of foods.

\section{Appendix II: ARCH Estimates}

We present ARCH/GARCH estimates, respectively for the real exchange rate of the Yen/Yuan (table A1) and the real exchange rate of the Yen/Dollar (table A2). Recall that EGARCH method (Nelson, 1991, Engle, 2004) can be advantageous to model exchange rate 
uncertainty for the two reasons. First, it allows for the asymmetry in the responsiveness of exchange uncertainty to the sign of shocks (innovation). Second, unlike GARCH specification, the EGARCH model, specified in logarithms, does not impose the nonnegativity constraints on parameters. Here, we retain the EViews specification of the EGARCH model as:

$$
\operatorname{Logh}_{t}=\omega+\sum_{i=1}^{q} \alpha_{i}\left|\left(\varepsilon_{t-i}\right) /\left(\sqrt{h_{t-i}}\right)\right|+\sum_{j=1}^{p} \beta_{j} \operatorname{Logh}_{t-j}+\sum_{k=1}^{r} \gamma_{k}\left[\left(\varepsilon_{t-k}\right) /\left(\sqrt{h_{t-k}}\right)\right]
$$

Table A1: Estimations results of the $\operatorname{ARCH}(1), \operatorname{GARCH}(1,1)$, and $\operatorname{EGARCH}(1,1)$ models for the Yen/Yuan quarterly real exchange rate, from 1970 Q2 to 2007Q4

\begin{tabular}{|c|c|c|c|c|c|c|}
\hline \multirow[b]{2}{*}{ Sectors } & \multirow[b]{2}{*}{ Model } & \multicolumn{5}{|c|}{ Estimated parameters } \\
\hline & & $\omega$ & $\alpha$ & $\beta$ & $\gamma$ & Log likelihood \\
\hline \multirow[t]{2}{*}{ Foods } & EGARCH $(1,1)$ & $-0.2809 *$ & $-0.2306 * *$ & -0.0042 & $0.9129 * *$ & 203.451 \\
\hline & & $(0.10)$ & $(0.05)$ & $(0.96)$ & $(0.00)$ & \\
\hline \multirow[t]{2}{*}{ Textile } & GARCH $(1,1)$ & 0.0004 & 0.0312 & $0.8537 * *$ & & 231.462 \\
\hline & & $(0.45)$ & $(0.59)$ & $(0.00)$ & & \\
\hline \multirow[t]{2}{*}{ Metal Prod. } & $\mathrm{ARCH}(1)$ & $0.0029 * *$ & 0.1475 & & & 215.331 \\
\hline & & $(0.00)$ & $(0.22)$ & & & \\
\hline \multirow[t]{2}{*}{ Chemicals } & $\mathrm{ARCH}(1)$ & $0.0029 * *$ & $0.2333 * *$ & & & 211.979 \\
\hline & & $(0.00)$ & $(0.02)$ & & & \\
\hline \multirow{2}{*}{$\begin{array}{l}\text { Non Metal } \\
\text { Pr. }\end{array}$} & EGARCH $(1,1)$ & $-9.2377 * *$ & -0.2482 & $0.4007 *$ & -0.5311 & 258.173 \\
\hline & & $(0.00)$ & $(0.33)$ & $(0.07)$ & $(0.12)$ & \\
\hline \multirow[t]{2}{*}{ Mat. Equip. } & GARCH $(1,1)$ & $0.00005^{* *}$ & $-0.0234 * *$ & $1.0252 * *$ & & 243.354 \\
\hline & & $(0.00)$ & $(0.00)$ & $(0.00)$ & & \\
\hline
\end{tabular}

Note: The entry in parentheses represents the P-values for the null hypothesis 
Table A2: Estimations results of the $\operatorname{ARCH}(1), \operatorname{GARCH}(1,1)$, and $\operatorname{EGARCH}(1,1)$ models for the Yen/Dollar quarterly real exchange rate, from 1970 Q2 to 2007Q4

\begin{tabular}{|c|c|c|c|c|c|c|}
\hline \multirow[b]{2}{*}{ Sectors } & \multirow[b]{2}{*}{ Model } & \multicolumn{5}{|c|}{ Estimated parameters } \\
\hline & & $\omega$ & $\alpha$ & $\beta$ & $\gamma$ & Log likelihood \\
\hline \multirow[t]{2}{*}{ Foods } & EGARCH $(1,1)$ & -0.3687 & -0.0127 & 0.0594 & $0.9357 * *$ & 238.933 \\
\hline & & $(0.14)$ & $(0.88)$ & $(0.23)$ & $(0.00)$ & \\
\hline \multirow[t]{2}{*}{ Textile } & GARCH $(1,1)$ & $0.0004 * *$ & $0.2544^{*}$ & $0.4828 * *$ & & 277.226 \\
\hline & & $(0.04)$ & $(0.10)$ & $(0.03)$ & & \\
\hline \multirow[t]{2}{*}{ Metal Prod. } & $\mathrm{ARCH}(1)$ & $0.0009 * *$ & $0.4227 * *$ & & & 282.079 \\
\hline & & $(0.00)$ & $(0.003)$ & & & \\
\hline \multirow[t]{2}{*}{ Chemicals } & $\mathrm{ARCH}(1)$ & $0.0008 * *$ & $0.4668 * *$ & & & 287.985 \\
\hline & & $(0.00)$ & $(0.001)$ & & & \\
\hline \multirow{2}{*}{$\begin{array}{l}\text { Non Metal } \\
\text { Pr. }\end{array}$} & $\operatorname{GARCH}(1,1)$ & $0.0001 * *$ & $0.3421 * *$ & $0.5063 * *$ & & 344.534 \\
\hline & & $(0.03)$ & $(0.03)$ & $(0.002)$ & & \\
\hline \multirow[t]{2}{*}{ Mat. Equip. } & $\mathrm{ARCH}(1)$ & $0.0009 * *$ & $0.2264 *$ & & & 293.854 \\
\hline & & $(0.00)$ & $(0.10)$ & & & \\
\hline
\end{tabular}

Note: The entry in parentheses represents the P-values for the null hypothesis 